\title{
Summer and Autumn Movements and Habitat Use by Belugas in the Canadian High Arctic and Adjacent Areas
}

\author{
P.R. RICHARD, ${ }^{1}$ M.P. HEIDE-JøRGENSEN,${ }^{2}$ J.R. ORR, ${ }^{1}$ R. DIETZ ${ }^{3}$ and T.G. SMITH ${ }^{4}$
}

\author{
(Received 18 November 1999; accepted in revised form 25 January 2001)
}

\begin{abstract}
Twenty-one adult belugas $(8 \mathrm{M}, 13 \mathrm{~F})$ were live-captured and instrumented with satellite-linked transmitters in the summer and fall of 1996. Twelve were captured in estuaries along the coast of Somerset Island in July and nine were captured in September in Croker Bay, SE Devon Island. This paper reports on the summer and autumn movements and dive depths of these animals from late July 1996 until the last tags ceased transmitting in November 1996. Of the 12 captured in July, 11 provided data for 30-126 days (mean $=84$ days). Most of the animals moved rapidly to southern Peel Sound, where they all spent the month of August, making frequent deep dives, some of which were to depths near or at the seabed of the Franklin Trench. The belugas also used several bays along the coast of Prince of Wales Island and another one on Melville Peninsula. They left southern Peel Sound between late August and early September and moved rapidly to the south coast of Devon Island, many using Maxwell Bay and Croker Bay for several days. All belugas instrumented in Croker Bay in September, as well as the summer-tagged individuals that were still transmitting, moved east and north along the south and east coasts of Devon Island, eventually reaching Jones Sound and north Baffin Bay. They used many bays along the east coast of Devon Island and dove to depths often exceeding $200 \mathrm{~m}$ in the surrounding waters. Fifteen of the tags continued to transmit during the period when belugas are normally observed migrating along the West Greenland coast (late September-early October). Only one of the tagged animals moved to Greenland waters in late September. The others remained in the area known in winter as the North Water. The autumn tracking results suggest that the North Water may harbour a larger winter population of belugas than was previously suspected.
\end{abstract}

Key words: beluga, Delphinapterus leucas, dive recording, High Arctic, North Water, satellite-linked tracking, swimming speed

RÉSUMÉ. Durant l'été et l'automne de 1996, on a capturé 21 bélugas adultes ( 8 mâles, 13 femelles), qu'on a équipés d'émetteurssatellite. Douze d'entre eux ont été capturés en juillet dans des estuaires de l'île Somerset et neuf autres l'ont été en septembre dans la baie Croker du sud-est de l'île Devon. Cet article fait état des déplacements et profondeurs de plongée de ces animaux en été et en automne, de la fin juillet 1996 jusqu'à ce que les émetteurs cessent de transmettre, en novembre 1996. Sur 12 individus capturés en juillet, 11 ont transmis des données pendant 30 à 126 jours (moy. $=84$ jours). La plupart des animaux se sont déplacés rapidement vers le sud du détroit de Peel où ils ont tous passé le mois d'août, plongeant fréquemment à de grandes profondeurs dont certaines atteignaient ou presque le fond marin de la fosse Franklin. Les bélugas ont aussi utilisé plusieurs baies le long de la côte de l'île Prince of Wales et une autre dans la péninsule Melville. Ils ont quitté le sud du détroit de Peel entre fin août et début septembre et se sont déplacés rapidement vers la côte sud de l'île Devon. Plusieurs d'entre eux ont passé quelques jours dans les baies Maxwell et Croker. Tous les bélugas équipés d'instruments dans la baie Croker en septembre, ainsi que ceux relâchés en été et qui continuaient à transmettre, se sont déplacés vers l'est et le nord en suivant les côtes sud et est de l'île Devon, finissant par atteindre le détroit de Jones et le nord de la baie de Baffin. Ils ont occupé de nombreuses baies sur la côte est de l'île Devon et effectué des plongées atteignant souvent plus de $200 \mathrm{~m}$ dans les eaux avoisinantes. Quinze des émetteurs ont continué à transmettre durant la période où on observe normalement des bélugas en migration au large de la côte du Groenland occidental (fin septembre-début octobre). Un seul des animaux portant un émetteur a pénétré dans les eaux groenlandaises à la fin septembre. Les autres sont restés dans une zone connue en hiver sous le nom de «North Water» (Eau du Nord). Ces résultats suggèrent qu'en hiver le «North Water» abrite une population de bélugas plus abondante qu'on ne le pensait antérieurement.

Mots clefs: béluga, Delphinapterus leucas, Extrême-Arctique, suivis télémétriques par satellite, plongée, vitesse de nage

\section{INTRODUCTION}

Thousands of belugas (Delphinapterus leucas) are known to spend July and August in the waters surrounding Somerset
Island in the Canadian High Arctic (Finley and Johnson, 1977; Koski and Davis, 1979, 1980). In September, High Arctic belugas are also known to migrate eastward along the south shore of Devon Island and north along its east

\footnotetext{
${ }^{1}$ Department of Fisheries and Oceans, Arctic Research Division, Freshwater Institute Science Lab, 501 University Crescent, Winnipeg, Manitoba R3T 2N6, Canada; richardp@dfo-mpo.gc.ca

${ }^{2}$ Greenland Institute of Natural Resources, Boks 570, D-3900 Nuuk, Greenland

${ }^{3}$ National Environmental Research Institute, Department of Arctic Environment, Tagensvej 135, DK-2200, Copenhagen N, Denmark

${ }^{4}$ E.M.C. Eco Marine Corporation, 5694 Camp Comfort Rd, Garthby, Quebec G0Y 1B0, Canada

(C) The Arctic Institute of North America
} 
shore (Koski and Davis, 1980; Smith and Martin, 1994). Thousands of belugas have also been observed migrating south along the northwest coast of Greenland, appearing in the Qaanaaq (formerly Avanersuaq) area in September and in the Upernavik area in early October (Thomsen, 1993; Heide-Jørgensen, 1994). These belugas were thought to be the same animals that migrate to central West Greenland, south of Disko Island, for the winter (Doidge and Finley, 1993). Hundreds of belugas have also been observed wintering in an area of northwest Baffin Bay and Smith Sound known as the North Water (Finley and Renaud, 1980; Richard et al., 1998a). The West Greenland winter population of belugas, once thought to be the largest winter component of the Canadian High Arctic stock, has experienced a severe decline in the last two decades (HeideJørgensen et al., 1993; Heide-Jørgensen and Reeves, 1996) and, in recent years, the numbers migrating past the Upernavik area in the autumn have diminished (HeideJørgensen, unpubl. data).

Belugas hunted by the community of Grise Fiord (Ellesmere Island, Canada) and those hunted in West Greenland attain similar size at physical maturity (HeideJørgensen and Teilmann, 1994; Stewart, 1994). The absence of morphological differences, however, does not prove that whales from the two areas belong to the same stock. New lines of evidence (DNA, contaminant ratios) suggest that there may be two stocks, one wintering in West Greenland and the other in the North Water (JCCM, 1995).

Satellite tracking of the movements of individuals offers the potential of obtaining direct evidence of beluga movements from summer range to wintering areas. The movements of belugas during the summer and the early part of their autumn migration in Barrow Strait and Lancaster Sound have been described by Smith and Martin (1994), who tracked 18 belugas (1 male, 17 females) with satellite-linked transmitters. Although some of their transmitters lasted into September, Smith and Martin were unable to track any belugas moving from Canadian to West Greenland waters because contact with the tagged whales was lost early in the autumn. This project, which involved radio-tracking an additional 21 belugas tagged in Somerset Island estuaries in July and in Croker Bay, Devon Island, in September, adds to the Smith and Martin results and offers new insights on habitat use by documenting the belugas' movements over a longer period of time.

\section{MATERIALS AND METHODS}

\section{Study Area}

The study area was defined by the areas used by tagged animals and included western Lancaster Sound, Prince Regent Inlet, Barrow Strait, Peel Sound, and numerous bays of Somerset and Prince of Wales Islands, Lancaster Sound, eastern Jones Sound, and northwestern Baffin Bay north to Smith Bay, southeast Ellesmere Island (Fig. 1).
One animal also migrated south along the east side of Baffin Bay to an area offshore of Disko Island, Greenland. Waters throughout the study area are for the most part deeper than $200 \mathrm{~m}$. Depths in the central portions of Prince Regent Inlet, eastern Barrow Strait and southern Peel Sound exceed $400 \mathrm{~m}$. Waters in western Barrow Strait are somewhat shallower, varying between 100 and $200 \mathrm{~m}$. Croker Bay, a fiord on the southeast coast of Devon Island, is about $40 \mathrm{~km}$ long, $15 \mathrm{~km}$ wide, and $100-400 \mathrm{~m}$ deep at its centre. A deep trough, with depths over $400 \mathrm{~m}$, runs north along the east coast of Devon Island and then west into Jones Sound, where depths in some parts exceed $800 \mathrm{~m}$. Waters east and southeast of Coburg Island and along eastern Ellesmere Island are somewhat shallower, varying between 100 and $400 \mathrm{~m}$. On the east side of Baffin Bay, depth varies, alternating between banks less than $200 \mathrm{~m}$ deep and trenches with depths over $800 \mathrm{~m}$.

In the last week of July 1996, eastern Barrow Strait was open and northern Prince Regent Inlet contained loose pack of 5/10 to 8/10 cover (Weekly Composite Ice Charts, Environment Canada). Peel Sound and southern Prince Regent Inlet had 9/10 to 10/10 ice cover. Between 31 July and 1 August, ice cover had diminished to between 1/10 and $9 / 10$ in western Barrow Strait and Peel Sound. Ice conditions lessened thereafter, but 5/10-7/10 moving pack ice remained in southern Peel Sound and Prince Regent Inlet throughout the summer. Loose multi-year ice was also present in Barrow Strait all summer. By 26 September 1996, most of the study area had between $6 / 10$ and $9 / 10$ ice cover, and by 10 October, most of the area had $9 / 10+$ ice cover, including considerable multi-year ice (Weekly Composite Ice Charts, Environment Canada). Fast ice did not form throughout Jones Sound in October 1996 as it often does (Markham, 1981). Instead, ice cover remained localized along the southeast coast of Ellesmere Island.

\section{Live-Capture and Tagging Methods}

Twelve belugas ( 8 females, 4 males) were captured between 15 and 25 July 1996 (Table 1 ) at three Somerset Island estuaries (Cunningham Inlet, Elwin Bay, and Creswell Bay) by restraining them along the shore using a hoop net made of a circular rim $1.2 \mathrm{~m}$ in diameter and a purse net $1.4 \mathrm{~m}$ deep (Orr et al., 2001). Three of the captured females were accompanied by large calves, presumed to be 1-3 years old because they were greycoloured and approximately $2 / 3$ of the size of the adult females (Caron and Smith, 1990; Doidge, 1990). One of these females was also accompanied by a neonate.

For the fall tagging attempts, a camp was established at the same location as in September 1995 (Richard et al., $1998 \mathrm{~b}$ ) on the southeast corner of Croker Bay (ca. $74^{\circ} 33^{\prime} \mathrm{N}$ $82^{\circ} 55^{\prime} \mathrm{W}$ ) between 21 August and 19 September. The methods of capture were the same as those for Somerset Island. A total of nine belugas ( 5 females, 4 males) were captured during that time. Two of the captured females were accompanied by calves (Table 1), presumed to be 


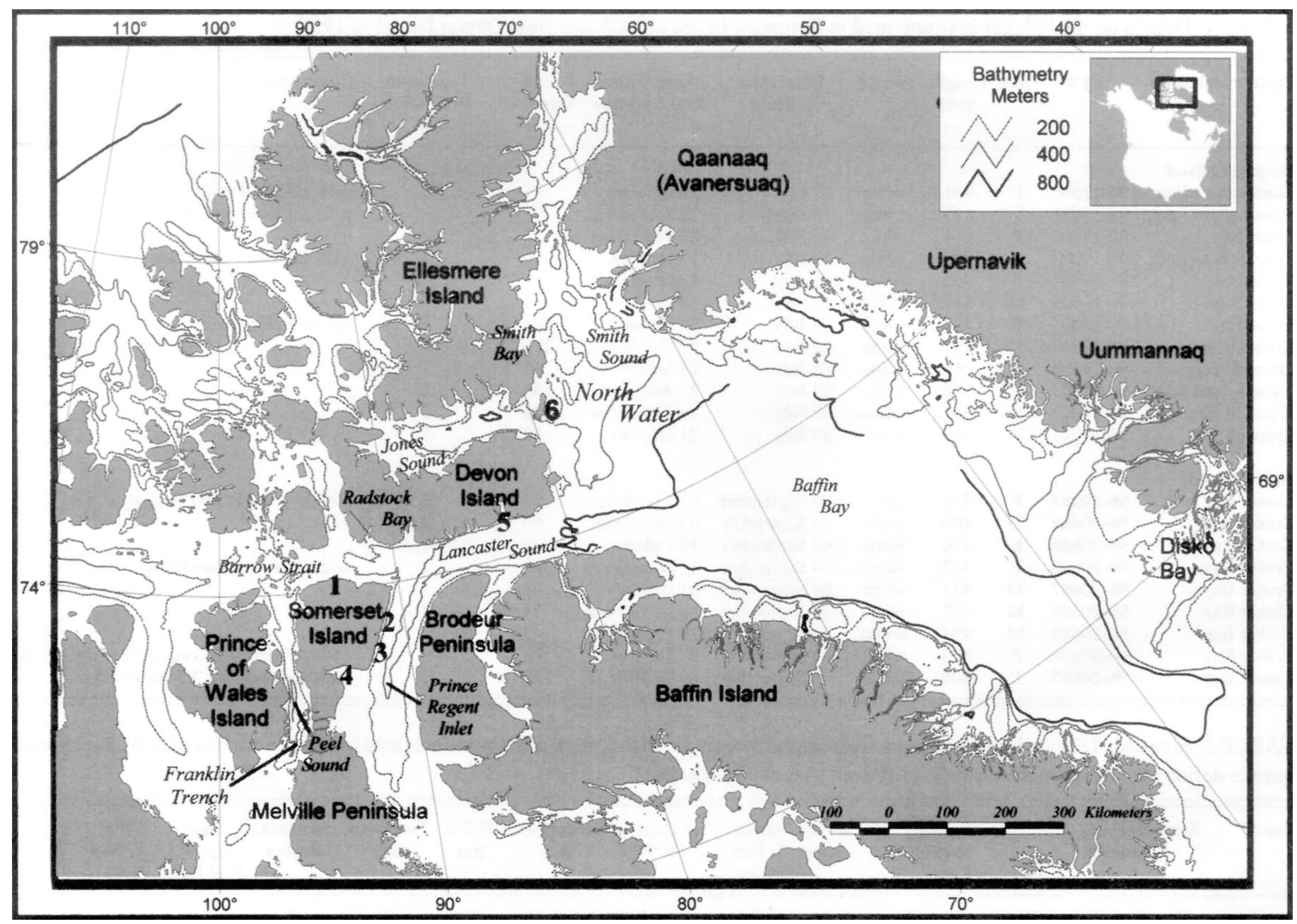

FIG. 1. Study area with place names, capture sites, and bathymetric contours (in m). Numbered locations are: 1 - Cunningham Inlet, 2 - Elwin Bay, 3 - Batty Bay, 4 - Creswell Bay, 5 - Croker Bay, 6 - Cobourg Island.

1-3 years old for the reasons given above. One of those two females also had a neonate, and a third female showed signs of recent suckling.

The tags, model ST6, were manufactured by Wildlife Computers Ltd. (Redmond, Washington, USA). Two types of tags were deployed: 1) a single-housing unit measuring $17.3 \times 9.7 \times 2.8 \mathrm{~cm}$ and fixed to a saddle-mount made of $1.5 \mathrm{~mm}$ thick belt material; 2) a two-housing unit with individual housing dimensions of $3 \times 4.5 \times 14 \mathrm{~cm}$ glued onto a flexible rubber saddle (Ureol polyurethane) $5 \mathrm{~mm}$ thick. Both types contained a transmitter, a pressure transducer, and a microprocessor cast in epoxy. The microprocessor controlled transmissions and processed time-depth data, which were stored in memory chips awaiting transmission. Each unit, powered by four lithium C cells ( $3.5 \mathrm{~V})$, had a power output of 0.5 watts and was capable of 54000 transmissions at $0^{\circ} \mathrm{C}$. None of the transmitters were set on a duty cycle, and the only battery-saving features were a daily maximum of 1000 transmissions and a saltwater switch that prevented transmissions after the switch was wet for more than $0.1 \mathrm{~s}$. The minimum time between transmissions was $45 \mathrm{~s}$. Each transmission contained 8 to
12 bytes of data in addition to the tag's identifier number. Following every 15 transmissions, a status message relayed information about the total number of transmissions and the voltage of batteries. Data from the transmitters were received via the ARGOS Data Collection and Location System (DCLS) (ARGOS, 1988).

The units were attached to the belugas by two or three $7-$ $8 \mathrm{~mm}$ polyethylene pins (PEHD 1000) through the dorsal ridge. The animals showed no visible reaction to the surgical procedure. The saddles were secured to the pins and held in place with washers and nuts. The ends of the pins were compressed to prevent the nuts from being torn off.

During the stay at the Croker Bay camp, reception from transmitters that were within detection range $(<5 \mathrm{~km}$ at sea level) was monitored using an UHF uplink receiver (Telonics).

The time-depth recorders had a depth resolution of $2 \mathrm{~m}$ and a dynamic range to $500 \mathrm{~m}$ for all but two tags, which had $4 \mathrm{~m}$ resolution and a dynamic range to $1000 \mathrm{~m}$. Dives were defined as depths lower than a certain threshold, 6 or $8 \mathrm{~m}$ depending on the tags. Tags were programmed to measure the greatest depth of each individual dive, 
TABLE 1. Details on the belugas instrumented at Somerset Island and Croker Bay, Devon Island in 1996.

\begin{tabular}{|c|c|c|c|c|c|c|c|c|c|}
\hline Capture location & Tag \# & Sex & $\begin{array}{l}\text { Length } \\
(\mathrm{cm})\end{array}$ & Colour & $\begin{array}{l}\text { Date/Time } \\
\text { Release }\end{array}$ & $\begin{array}{l}\text { Date/Time } \\
\text { Last Location }\end{array}$ & $\begin{array}{l}\text { Tag } \\
\text { Duration } \\
\text { (d) }\end{array}$ & $\begin{array}{l}\text { Tag Depth } \\
\text { Resolution } \\
\quad(\mathrm{m})\end{array}$ & Comments \\
\hline \multicolumn{10}{|l|}{ Somerset Island: } \\
\hline Cunningham Inlet & $96-17000$ & $\mathrm{~F}$ & 431 & white & 15 July & 20 October & 97 & 2 & with $2 / 3$ sized calf \\
\hline Cunningham Inlet & 96-17001 & $\mathrm{F}$ & 415 & white & 18 July & 29 September & 73 & 2 & with $2 / 3$ sized calf \\
\hline Elwin Bay & 96-17002 & $\mathrm{F}$ & 386 & white & 16 July & 23 September & 68 & 2 & \\
\hline Cunningham Inlet & $96-17003$ & $\mathrm{~F}$ & 392 & white & 19 July & 13 October & 86 & 2 & with neonate $+2 / 3$ sized calf \\
\hline Elwin Bay & 96-17004 & $\mathrm{F}$ & 401 & white & 16 July & 12 October & 87 & 2 & \\
\hline Elwin Bay & $96-17005$ & $\mathrm{M}$ & 478 & white & 17 July & 18 July & 1 & 2 & \\
\hline Elwin Bay & $96-17006$ & $\mathrm{~F}$ & 396 & white & 19 July & 30 October & 103 & 2 & old wound in left eye \\
\hline Creswell Bay & $96-17007$ & M & 417 & white & 22 July & 30 October & 100 & 2 & \\
\hline Creswell Bay & 96-17008 & $\mathrm{F}$ & 366 & white & 25 July & 24 September & 61 & 2 & \\
\hline Cunningham Inlet & 96-17009 & $\mathrm{F}$ & 348 & grey & 22 July & 21 August & 30 & 2 & \\
\hline Creswell Bay & $96-17010$ & M & 457 & white & 25 July & 28 November & 126 & 2 & \\
\hline Creswell Bay & $96-17011$ & M & 386 & grey & 25 July & 21 October & 88 & 2 & \\
\hline \multicolumn{10}{|l|}{ Devon Island: } \\
\hline Croker Bay & $96-20683$ & $\mathrm{~F}$ & 354 & grey & 03 September & 02 November & 60 & 2 & with large light grey animal \\
\hline Croker Bay & $96-20684$ & M & 400 & white & 04 September & 03 November & 60 & 2 & \\
\hline Croker Bay & $96-20685$ & $\mathrm{~F}$ & 370 & white & 04 September & 19 October & 45 & 2 & \\
\hline Croker Bay & $96-20686$ & $\mathrm{~F}$ & 412 & white & 04 September & 12 November & 69 & 2 & might have been suckling \\
\hline Croker Bay & $96-20687$ & M & 423 & white & 04 September & 31 October & 56 & 2 & \\
\hline Croker Bay & $96-20688$ & $\mathrm{M}$ & 487 & white & 07 September & 18 November & 71 & 4 & \\
\hline Croker Bay & $96-20689$ & M & 454 & white & 08 September & 10 September & 2 & 2 & \\
\hline Croker Bay & $96-20690$ & $\mathrm{~F}$ & 400 & white & 14 September & 27 October & 43 & 4 & with $2 / 3$ sized calf and other white animal \\
\hline Croker Bay & $96-20693$ & $\mathrm{~F}$ & 405 & white & 05 September & 23 October & 48 & 2 & with newborn and $2 / 3$ sized calf \\
\hline
\end{tabular}

TABLE 2. Area use of Prince Regent Inlet and Peel Sound by belugas instrumented at Somerset Island in July 1996. (Use of S. W. Peel Sound bays is defined as one or more location in the bays on any given day.)

\begin{tabular}{|c|c|c|c|c|c|c|c|c|c|c|c|c|}
\hline Tag \# & Sex & $\begin{array}{l}\text { Tagging } \\
\text { location }\end{array}$ & $\begin{array}{l}\text { Prince } \\
\text { Regent } \\
\text { Bays }\end{array}$ & $\begin{array}{l}\text { Bellot } \\
\text { Strait }\end{array}$ & $\begin{array}{l}\text { Arrive } \\
\text { S. Peel } \\
\text { Sound }\end{array}$ & $\begin{array}{l}\text { Days to } \\
\text { S. Peel }\end{array}$ & $\begin{array}{c}\text { Coningham } \\
\text { Bay }\end{array}$ & $\begin{array}{c}\text { Willis } \\
\text { Bay }\end{array}$ & $\begin{array}{c}\text { Transition } \\
\text { Bay }\end{array}$ & $\begin{array}{l}\text { Strzelecki } \\
\text { Harbor }\end{array}$ & $\begin{array}{c}\text { Days } \\
\text { in S.W. } \\
\text { Peel Bays }\end{array}$ & $\begin{array}{l}\text { Other } \\
\text { S. Peel } \\
\text { Bays }\end{array}$ \\
\hline $96-17000$ & $\mathrm{~F}$ & Cunningham Inlet & & & 20 July & 5 & $*$ & $*$ & $*$ & $*$ & 31 & Wrottesley \\
\hline $96-17001$ & $\mathrm{~F}$ & Cunningham Inlet & & & 20 July & 2 & $*$ & $*$ & $*$ & $*$ & 14 & \\
\hline $96-17002$ & $\mathrm{~F}$ & Elwin Bay & & $*$ & 24 July & 7 & $*$ & $*$ & $*$ & $*$ & 11 & \\
\hline $96-17003$ & $\mathrm{~F}$ & Cunningham Inlet & Creswell & & 21 July & 1 & $*$ & $*$ & $*$ & $*$ & 13 & \\
\hline $96-17004$ & $\mathrm{~F}$ & Elwin Bay & Batty, Creswell & $1 *$ & 01 August & 15 & $*$ & $*$ & $*$ & $*$ & 4 & Wrottesley \\
\hline $96-17006$ & $\mathrm{~F}$ & Elwin Bay & & & 28 July & 8 & $*$ & $*$ & $*$ & $*$ & 22 & Wrottesley \\
\hline $96-17007$ & M & Creswell Bay & & & 01 August & 9 & & $*$ & $*$ & $*$ & 3 & Wrottesley \\
\hline $96-17008$ & $\mathrm{~F}$ & Creswell Bay & & & 17 August & 23 & $*$ & $*$ & $*$ & $*$ & 10 & \\
\hline 96-17009 & $\mathrm{F}$ & Cunningham Inlet & & & 26 July & 3 & $*$ & $*$ & $*$ & $*$ & 17 & \\
\hline $96-17010$ & $\mathrm{M}$ & Creswell Bay & Elwin & & 01 August & 6 & $*$ & $*$ & $*$ & $*$ & 11 & Aston \\
\hline $96-17011$ & $\mathrm{M}$ & Creswell Bay & & $*$ & 01 August & 6 & $*$ & $*$ & $*$ & $*$ & 8 & \\
\hline
\end{tabular}

determine the depth category or "bin" into which it fell, and add that dive to the frequency count for that bin. The counts for each bin increased during each $6 \mathrm{~h}$ sampling period. At the end of the six-hour period, the bin counters were reset to zero for the next sampling period (Wildlife Computers, 1994). Dive data were transmitted in packets when the animal surfaced and were re-assembled after reception using Wildlife Computer's SATPAK program.

\section{Analytical Methods}

If four or more signals were received during a satellite pass, the ARGOS DCLS calculated the location of the tag and assessed the precision of that calculated position (ARGOS, 1996). Distances were calculated using great circle arcs on a spherical model of the globe of $6371.11 \mathrm{~km}$ radius (Maling, 1989, 1993). We used good-quality locations with predicted errors of $1 \mathrm{~km}$ or less (quality indices $1-3$ ) to determine the range of the belugas' swimming speeds over the range of elapsed times. Swimming speeds were estimated using the great circle distance and the elapsed time between consecutive locations. To obtain more locations for plotting movements, we filtered locations of ARGOS quality less than 1 (so-called "nonguaranteed") using a graded filter made from the above range of swim speeds. Low-quality locations were kept if the swim speed calculated from the preceding location was $10 \mathrm{~km} / \mathrm{hr}$ or less (or $20 \mathrm{~km} / \mathrm{hr}$ or less, if the second location was estimated within two hours). Locations and movement tracks were displayed in Arcview GIS (ESRI Inc.) on polar azimuthal base maps and checked for locations more than $1 \mathrm{~km}$ inland or for abrupt departures from travel direction that were followed by an equally abrupt return close to the initial location. 


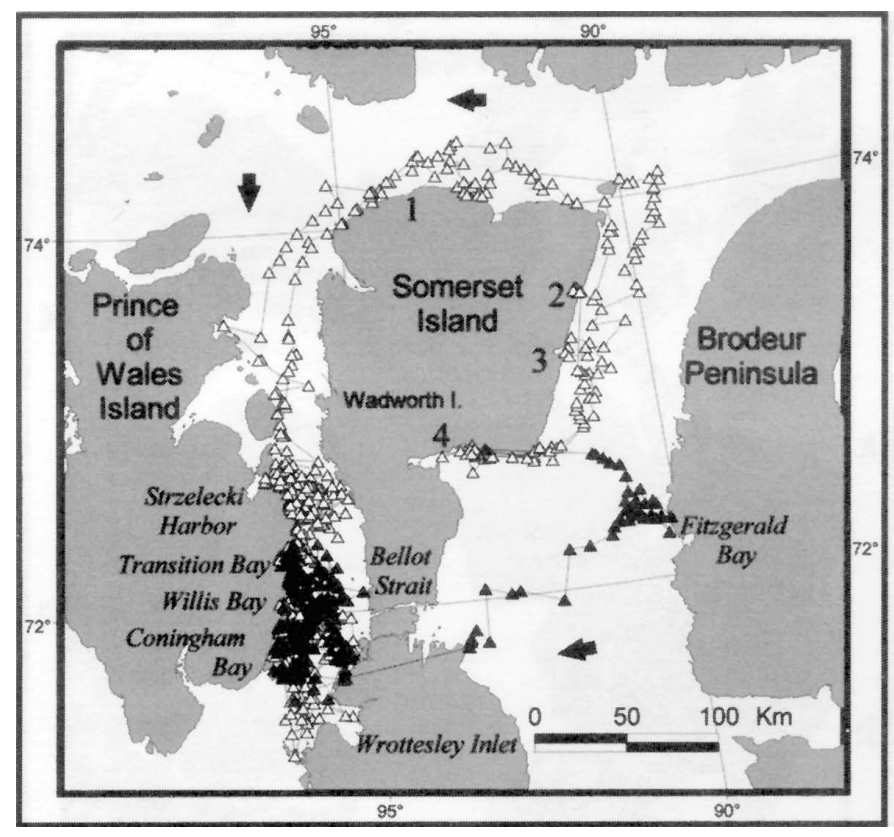

FIG. 2. Movements between 17 July and 15 August 1996 of male belugas instrumented at Somerset Island. $\boldsymbol{\Delta}=$ locations of male 96-17011, which crossed Bellot Strait. See Fig. 1 for numbered locations.

There are two sources of error in the estimation of swimming speeds. For short time intervals, the imprecision of locations results in diminished or exaggerated swimming speed estimates because of the small denominator (time). For long time intervals, estimates of swimming speed are biased downward when the whale's movements between the locations used to calculate travel distance were not in a straight line. To reduce the effect of such errors in analyses, we calculated swimming speeds only for intervals between locations that were between $0.5 \mathrm{hr}$ and $2 \mathrm{hr}$ apart.

Dive depth bins chosen for the $2 \mathrm{~m}$ resolution tags attached at Somerset Island and Croker Bay varied. For analyses, however, they were grouped into the following bins: less than $50 \mathrm{~m}, 50-100 \mathrm{~m}, 100-200 \mathrm{~m}, 200-300 \mathrm{~m}$, $300-400 \mathrm{~m}$, and 400+ m. Two Croker Bay tags had $1 \mathrm{~m}$ resolution and their dive depth bins were as above with these additional bins: $400-500 \mathrm{~m}, 500-600 \mathrm{~m}, 600-700 \mathrm{~m}$, $700-800 \mathrm{~m}, 800-900 \mathrm{~m}$, and $900+\mathrm{m}$. The proportion of dives in each of those depth bins was then calculated for each animal. Summary statistics were computed on these proportions for each sex and overall.

\section{RESULTS AND DISCUSSION}

\section{Post-Tagging Behaviour and Tag Performance}

Of the 12 tags attached to belugas in estuaries of Somerset Island in July, one (Elwin Bay male 96-17005) failed after a day (Table 1). The remaining 11 lasted for 30 to 126 days (mean $=84 \mathrm{~d}$ ). Of the nine tags attached to belugas in Croker Bay in September, one (male 96-20689) failed

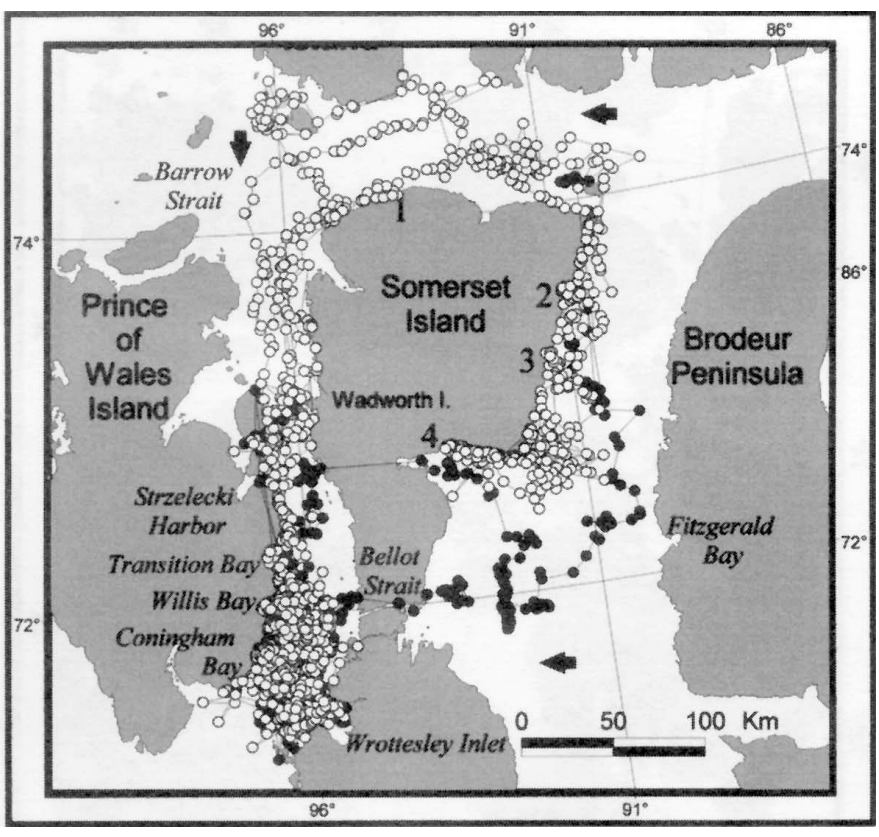

FIG. 3. Movements between 17 July and 15 August 1996 of female belugas instrumented at Somerset Island. $\boldsymbol{0}=$ locations of females 96-17002 and 9617003, which crossed Bellot Strait. See Fig. 1 for numbered locations.

after two days, and the rest transmitted for 43 to 71 days $($ mean $=57 \mathrm{~d})$.

\section{Summer Movements and Area Use}

Of the 11 Somerset belugas with functioning tags, 9 went to southern Peel Sound, within one to nine days (Table 2, Figs. 2 and 3). The remaining two took longer to make their way there. Elwin Bay female 96-17004 stayed in Prince Regent Inlet, visiting both Batty Bay and Creswell Bay during the first ten days, before returning north and moving to Peel Sound via Barrow Strait. It arrived there on 1 August, 15 days after its release. Creswell Bay female 96-17010 stayed in the area of Creswell Bay and Prince Regent Inlet before departing for southern Peel Sound, which it reached on 17 August, 23 days after its release. Smith and Martin (1994) documented arrival dates in Peel Sound between 24 July and 7 August by 11 belugas tagged in July of 1990-93. These dates are comparable to those for our 11 animals, all but one of which arrived in Peel Sound between 20 July and 1 August.

The belugas reached southern Peel Sound from two directions. One Cunningham Inlet female (96-17003), an Elwin Bay female (96-17002), and a Creswell Bay male (96-17011) went south into Prince Regent Inlet and crossed into Peel Sound through Bellot Strait (Table 2, Fig. 3). One of these, Elwin female 96-17002, visited Creswell Bay first and then stopped giving locations until it reappeared in Peel Sound 10 hours later. The only likely passage to Peel Sound in such a short time is through Bellot Strait.

To our knowledge, this is the first documented use of Bellot Strait by belugas. Smith and Martin (1994) reported that neither they nor Finley and Johnson (1977) observed 


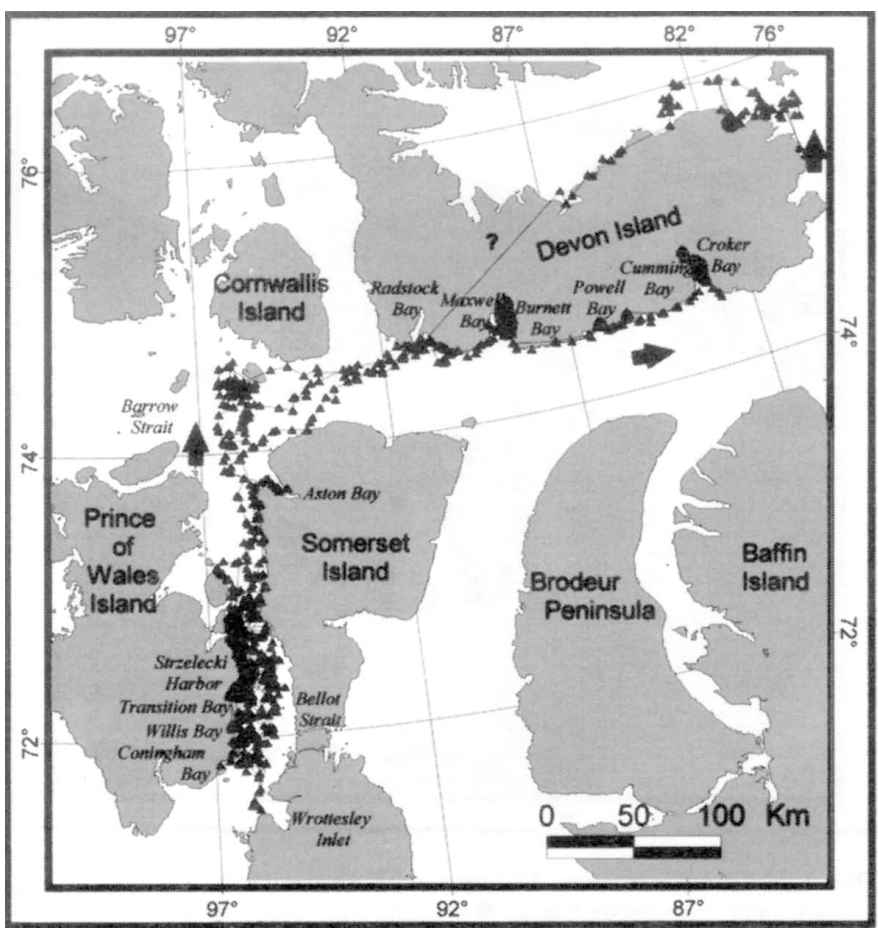

FIG. 4. Movements between 15 August and 15 September of male belugas instrumented at Somerset Island. The overland track with a question mark refers to male 96-17011, whose locations were lost near Radstock Bay and recovered two days later in Sverdrup Inlet, Jones Sound. The whale's actual track during that time is therefore unknown.

belugas in this strait, despite its use by narwhals (Monodon monoceros) and harp seals (Phoca groenlandica). They also mentioned that belugas enter Creswell Bay and Batty Bay as well as small rivers along the west coast of Brodeur Peninsula. Male 96-17011 and female 96-17003 gave locations near that coast, north of Fitzgerald Bay (Figs. 2 and 3), and one location of 96-17011 was close to the mouth of the Brodeur River.

The other eight whales followed Barrow Strait to reach Peel Sound, except for one Cunningham female (96-17001) whose trajectory is unknown because it gave no locations for two days after its release until it reappeared in southern Peel Sound. We assume that it travelled via Barrow Strait, given the short time between its release and its reappearance.

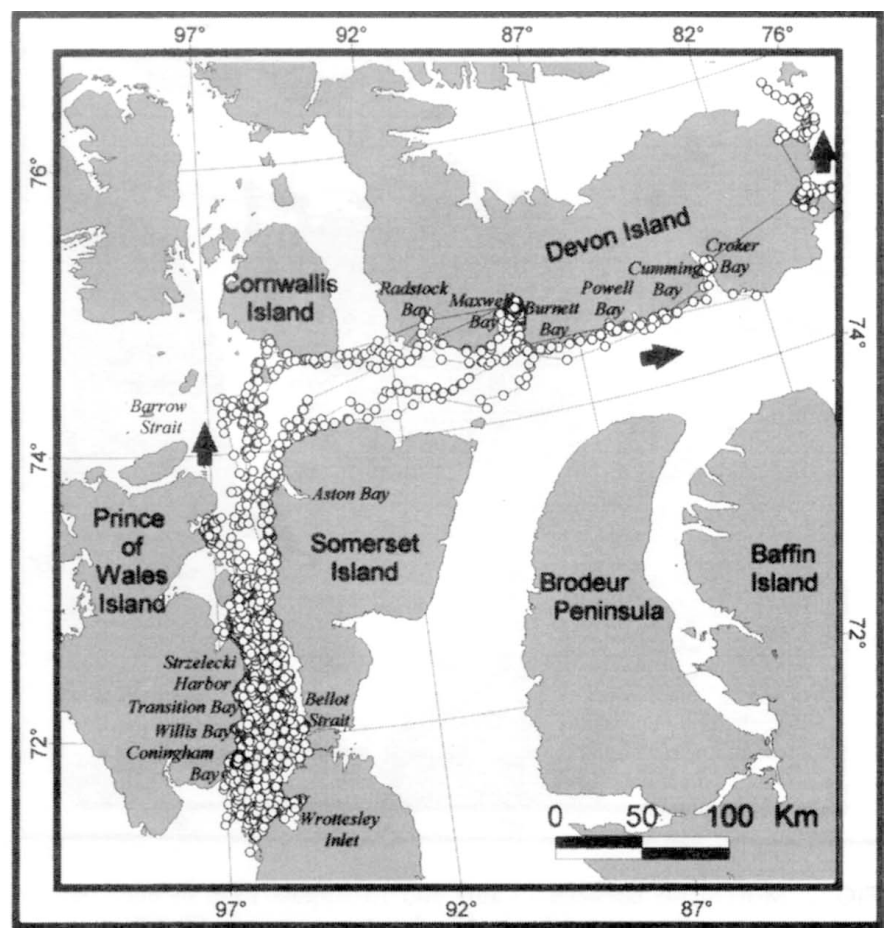

FIG. 5. Movements between 15 August and 15 September of female belugas instrumented at Somerset Island.

While in southern Peel Sound, all tagged belugas concentrated their activity in or near one or more bays along the Prince of Wales Island coast (Fig.4, Tables 2 and 3): Transition (Kennedy) Bay, Willis Bay, and Coningham Bay. Each has one or more river mouths in or near which large groups of belugas were seen during an aerial survey in August 1996 (P. Richard, unpubl. data). The number of days with at least one location in those three bays varied between individuals (Table 2). Females, particularly those accompanied by calves, generally appeared to spend the most time in bays. Another bay to the north, Strzelecki Harbor, was also used by all of the tagged animals.

All but one tagged beluga (Creswell male 96-17007) made daily trips from the coast of Prince of Wales Island to an area of deep water called the Franklin Trench in the

TABLE 3. Area use of Barrow Strait and Lancaster Sound by belugas instrumented at Somerset Island in July 1996.

\begin{tabular}{|c|c|c|c|c|c|c|c|}
\hline Tag \# & Sex & $\begin{array}{c}\text { Depart } \\
\text { S. Peel Sound }\end{array}$ & $\begin{array}{l}\text { Days in } \\
\text { Barrow Strait }\end{array}$ & $\begin{array}{l}\text { Use of bays west } \\
\text { of Maxwell Bay }\end{array}$ & $\begin{array}{c}\text { In or Near } \\
\text { Maxwell Bay }\end{array}$ & $\begin{array}{l}\text { Days Inside } \\
\text { Maxwell Bay }\end{array}$ & $\begin{array}{l}\text { Bays used between } \\
\text { Maxwell Bay and Croker Bay }\end{array}$ \\
\hline $96-17000$ & $\mathrm{~F}$ & 04 September & 1 & & 08 September & 6 & Burnett \\
\hline $96-17001$ & $\mathrm{~F}$ & 03 September & 3 & Radstock & 07 September & 8 & \\
\hline $96-17002$ & $\mathrm{~F}$ & 27 August & 2 & & 01 September & 11 & \\
\hline $96-17003$ & $\mathrm{~F}$ & 30 August & 6 & Radstock & 08 September & 7 & \\
\hline $96-17004$ & $\mathrm{~F}$ & 02 September & 2 & & 06 September & 9 & Burnett, Powell, Cumming \\
\hline $96-17006$ & $\mathrm{~F}$ & 09 September & 3 & Aston & 18 September & 0 & \\
\hline $96-17007$ & M & 20 August & 2 & & 25 August & 19 & Burnett, Powell \\
\hline $96-17008$ & $\mathrm{~F}$ & 10 September & 2 & & 14 September & 0 & \\
\hline $96-17009$ & $\mathrm{~F}$ & & & & & & \\
\hline $96-17010$ & M & 26 August & 2 & Aston, Radstock & 01 September & 10 & Burnett, Powell \\
\hline $96-17011$ & M & 20 August & 2 & & & & \\
\hline
\end{tabular}




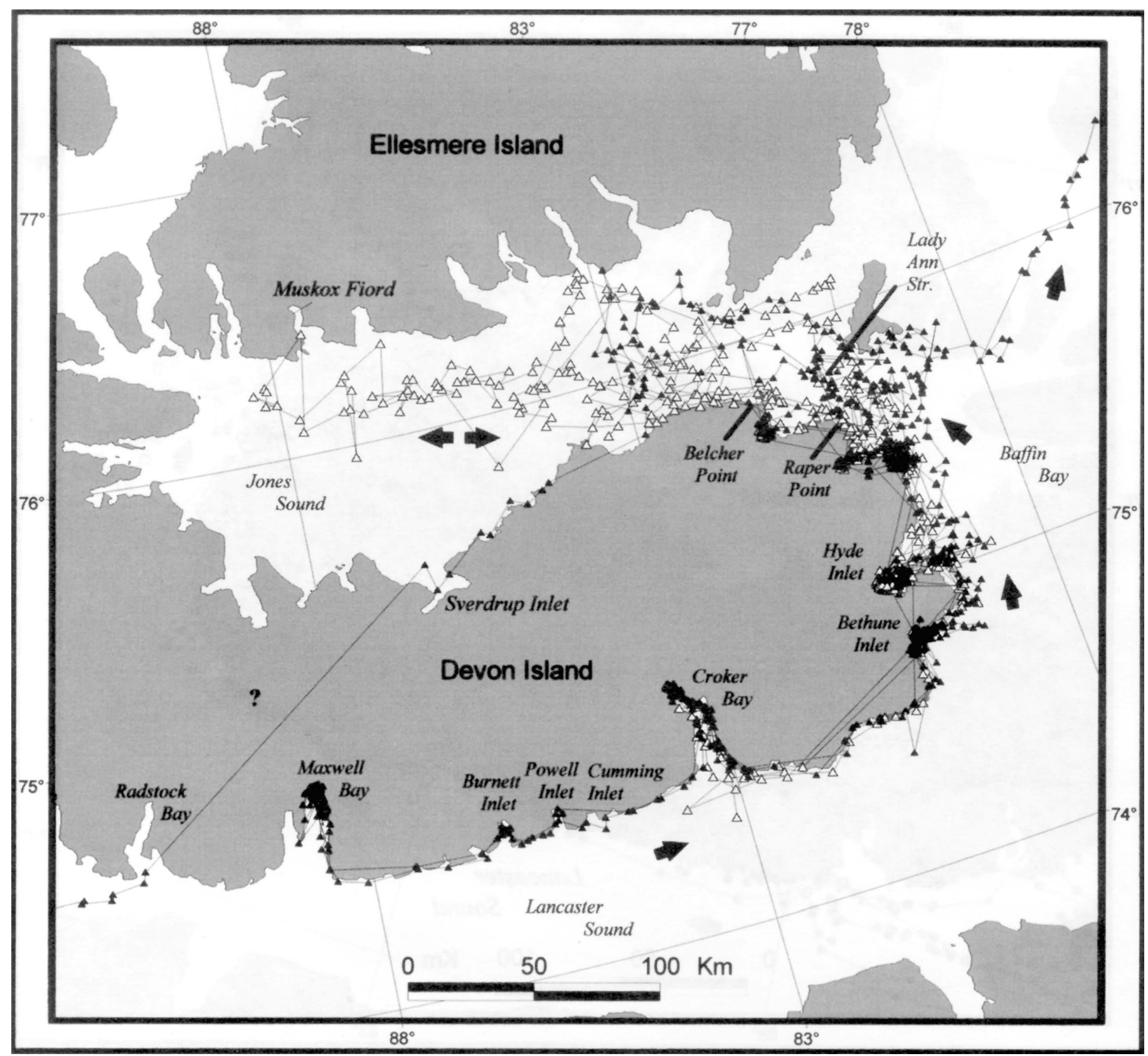

FIG. 6. Movements between 1 September and 1 October of male belugas instrumented at Somerset Island (closed triangles) and Croker Bay (open triangles). The overland track with a question mark refers to male 96-17011, whose locations were lost near Radstock Bay and recovered two days later in Sverdrup Inlet, Jones Sound. The whale's actual track during that time is therefore unknown.

centre of southern Peel Sound. These same animals also occasionally moved to the east side of the sound. On the east side of southern Peel Sound, Wrottesley Inlet on the coast of Boothia Peninsula was used by one male and three females (Figs. 2 and 3, Table 2). Following these incursions to the centre or east side, the belugas invariably returned to the bays or adjacent coastline of Prince of Wales Island.

Smith and Martin (1994) reported the use of Maxwell Bay on Devon Island and of the "estuary north of Wadworth Island" on the west coast of Somerset Island early in the summer, but except for female 96-17000, which spent a few hours in the coastal area north of Wadworth Island, none of the belugas tagged in 1996 occupied these places in the early summer. Smith and Martin also reported that belugas used Coningham Bay and the Franklin Trench, but they did not observe the use of Wrottesley Bay, Transition Bay, Willis Bay, or Strzelecki Harbor.

The belugas left southern Peel Sound between $20 \mathrm{Au}$ gust and 10 September, moving north into Barrow Strait and Lancaster Sound (Figs. 4 and 5, Table 3). One female (96-17002) and one male (96-17010) made a brief passage into Aston Bay on the northwestern coast of Somerset Island, and the same male and two females (96-17001 and 


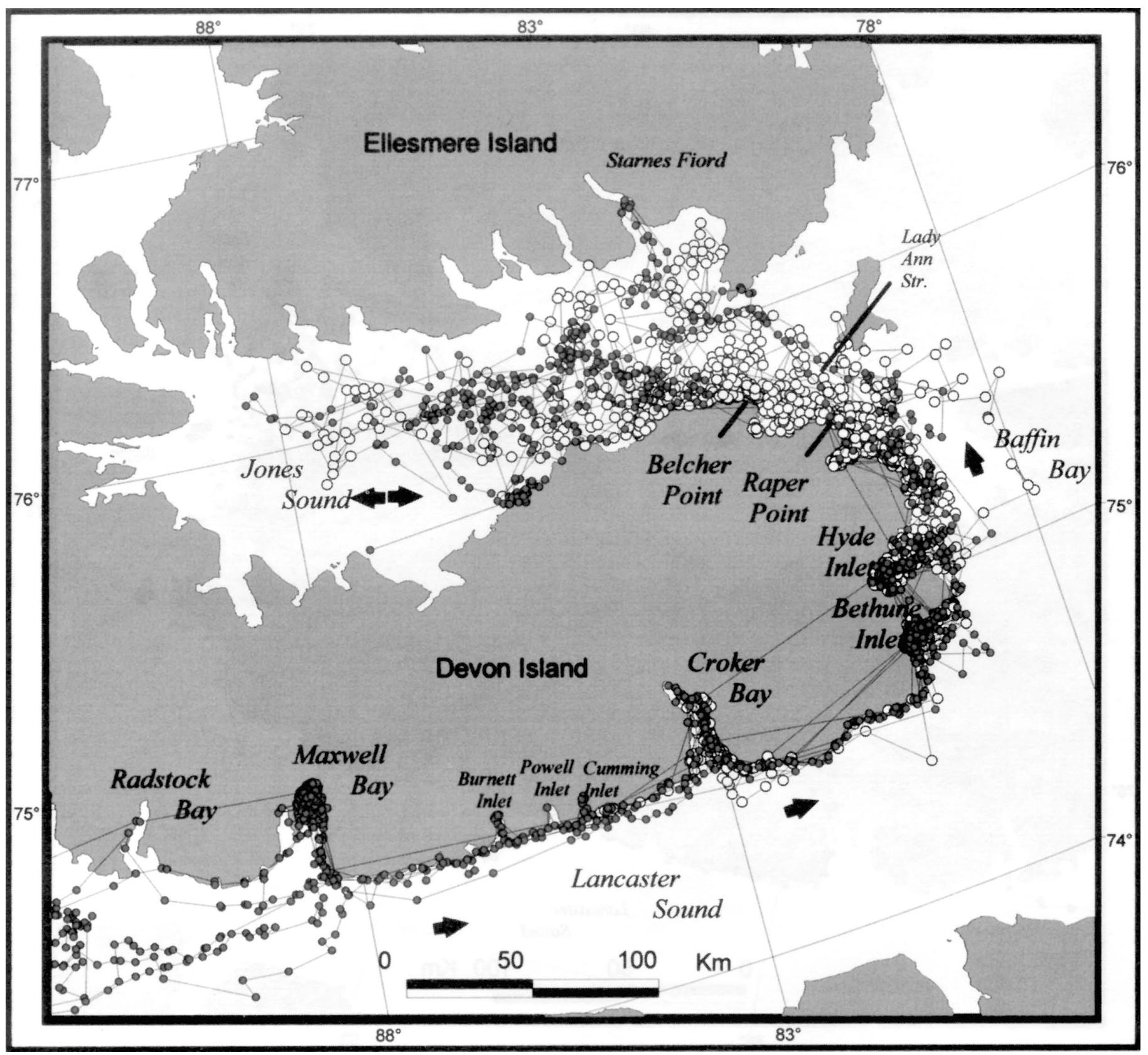

FIG. 7. Movements between 1 September and 1 October of female belugas instrumented at Somerset Island (closed circles) and Croker Bay (open circles).

96-17003) briefly entered Radstock Bay, southwestern Devon Island. Seven of the belugas made a prolonged stop in Maxwell Bay, farther east on Devon Island. Creswell male 96-17007 arrived there the earliest (August 25) and remained there until 13 September (19 days). Another Creswell male (96-17010) and four Cunningham and Elwin females (96-17001, 96-17002, 96-17003, and 96-17004) arrived in Maxwell Bay between 1 and 8 September and stayed there 6 to 11 days before continuing farther east along the Devon coast. On their migration east, four of the belugas briefly entered other bays east of Maxwell Bay.

Six of the belugas tagged by Smith and Martin (1994) departed from Peel Sound between 22 August and 7 September, compared to the departure dates of 20 August to 10
September for the 11 animals we tagged (Table 3). The belugas they tagged transited rapidly through Barrow Strait and arrived in Lancaster Sound between 24 August and 12 September. In comparison, all of our tagged belugas arrived in or near Maxwell Bay between 25 August and 18 September.

The use of bays in Peel Sound is probably related to the tendency of belugas to enter estuaries in summer (Smith and Martin, 1994). Belugas often seek river mouths at that time of the year where they find relatively warm brackish water, which may promote their skin moult (St. Aubin et al., 1990). Their use of bays in Barrow Strait and Lancaster Sound may be related to the presence of large schools of arctic cod (Boreogadus saida) along the shores of Devon 
TABLE 4. Area use by belugas instrumented at Somerset Island and Croker Bay in 1996.

\begin{tabular}{|c|c|c|c|c|c|c|c|c|c|c|c|c|c|}
\hline \multirow[t]{2}{*}{$\begin{array}{l}\text { Tagging } \\
\text { Location }\end{array}$} & \multirow[t]{2}{*}{ Tag \# } & \multirow[t]{2}{*}{ Sex } & \multicolumn{2}{|c|}{$\begin{array}{c}\text { Croker } \\
\text { Bay }^{1}\end{array}$} & \multirow{2}{*}{$\begin{array}{l}\text { Lancaster } \\
\text { Sound } \\
\text { Number } \\
\text { of Days } \\
\text { in Area }\end{array}$} & \multirow{2}{*}{$\begin{array}{l}\text { East Devon } \\
\text { Island } \\
\text { Days along } \\
\text { Prior to } \\
\text { Jones Sound }\end{array}$} & \multicolumn{3}{|c|}{$\begin{array}{l}\text { Jones } \\
\text { Sound }\end{array}$} & \multicolumn{3}{|c|}{$\begin{array}{l}\text { Smith } \\
\text { Sound }\end{array}$} & \multirow{2}{*}{$\begin{array}{c}\text { Date } \\
\text { of Last } \\
\text { Location }\end{array}$} \\
\hline & & & $\begin{array}{c}\text { Date } \\
\text { of First } \\
\text { Location }\end{array}$ & $\begin{array}{l}\text { Number } \\
\text { of Days } \\
\text { in }\end{array}$ & & & $\begin{array}{c}\text { Days } \\
\text { to }\end{array}$ & $\begin{array}{c}\text { Date D } \\
\text { of Last } \\
\text { Location a }\end{array}$ & $\begin{array}{l}\text { Days from } \\
\text { First } \\
\text { arrival in }\end{array}$ & $\begin{array}{c}\text { Date } \\
\text { of First } \\
\text { Location }\end{array}$ & $\begin{array}{c}\text { Date } \\
\text { of Last } \\
\text { Location }\end{array}$ & $\begin{array}{l}\text { Days } \\
\text { in }\end{array}$ & \\
\hline Croker & $96-20683$ & $\mathrm{~F}$ & 03 September & 4 & 4 & 3 & 7 & 06 October & 26 & - & - & - & 02 November \\
\hline Croker & $96-20685$ & $\mathrm{~F}$ & 04 September & 1 & 1 & 5 & 6 & 19 October & 39 & - & - & - & 19 October \\
\hline Croker & $96-20684$ & M & 04 September & 1 & 0 & 6 & 6 & 04 October & 24 & 10 October & 02 November & r 8 & 03 November \\
\hline Croker & $96-20686$ & $\mathrm{~F}$ & 04 September & 5 & 6 & 2 & 8 & 12 November & r 61 & - & - & - & 12 November \\
\hline Croker & $96-20687$ & M & 04 September & 0 & 1 & 23 & 24 & 04 October & 5 & - & - & - & 31 October \\
\hline Croker & $96-20693$ & $\mathrm{~F}$ & 05 September & 1 & 1 & 19 & 21 & 08 October & 12 & - & - & - & 23 October \\
\hline Croker & $96-20688$ & M & 07 September & 0 & 1 & 34 & 35 & 14 October & 2 & 21 October & 18 November & r 16 & 18 November \\
\hline Croker & $96-20689$ & M & 08 September & 2 & 2 & & - & - & - & - & - & - & 10 September \\
\hline Croker & $96-20690$ & $\mathrm{~F}$ & 14 September & 0 & 1 & 6 & 7 & 11 October & 20 & - & - & - & 27 October \\
\hline Somerset & $96-17001$ & $\mathrm{~F}$ & 08 September & 0 & 0 & 7 & 7 & 29 September & r 13 & - & - & - & 29 September \\
\hline Somerset & $96-17010$ & $\mathrm{M}$ & 14 September & 4 & 5 & 14 & 19 & 07 October & 4 & 08 October & 27 November & r 24 & 28 November \\
\hline Somerset & $96-17007$ & $\mathrm{M}$ & 14 September & 2 & 2 & 2 & 5 & 21 September & 2 & - & - & - & 30 October \\
\hline Somerset & $96-17000$ & $\mathrm{~F}$ & 15 September & 1 & 2 & 4 & 6 & 20 October & 29 & 09 October & 10 October & 2 & 20 October \\
\hline Somerset & $96-17011$ & M & 3 & 3 & 3 & 3 & 3 & 15 September & 3 & - & - & - & 21 October \\
\hline Somerset & $96-17002$ & $\mathrm{~F}$ & 15 September & - & 2 & 2 & 2 & 2 & 2 & 2 & 2 & 2 & 23 September \\
\hline Somerset & $96-17008$ & $\mathrm{~F}$ & 15 September & 1 & 2 & - & - & - & - & - & - & - & 24 September \\
\hline Somerset & $96-17003$ & $\mathrm{~F}$ & 17 September & 0 & 1 & 2 & 2 & 2 & 2 & 2 & 2 & 2 & 13 October \\
\hline Somerset & $96-17006$ & $\mathrm{~F}$ & 20 September & 0 & 1 & 2 & 2 & 2 & 2 & 2 & 2 & 2 & 30 October \\
\hline Somerset & $96-17004$ & $\mathrm{~F}$ & 21 September & 0 & 1 & 2 & 2 & 2 & 2 & 2 & 2 & 2 & 12 October \\
\hline
\end{tabular}

${ }^{1}$ First location is release date for whales tagged in Croker Bay (96-20683 to 20693).

${ }^{2}$ Remained along E. Devon Island or E. Lancaster Sound.

${ }^{3}$ Locations stopped in Radstock Bay and restarted in Jones Sound.

TABLE 5. Use of bays and fiords by belugas instrumented at Somerset Island in July 1996 and at Croker Bay in September 1996. (Use is measured by the number of days with at least one location.)

\begin{tabular}{|c|c|c|c|c|c|c|c|c|c|c|c|}
\hline $\begin{array}{l}\text { Tagging } \\
\text { Location }\end{array}$ & Tag \# & Sex & $\begin{array}{l}\text { Bethune } \\
\text { Inlet }\end{array}$ & $\begin{array}{l}\text { Hyde } \\
\text { Inlet }\end{array}$ & $\begin{array}{c}\text { Bay N of } \\
\text { Raper Point }\end{array}$ & $\begin{array}{c}\text { Bay S of } \\
\text { Belcher Point }\end{array}$ & $\begin{array}{l}\text { First Bay E of } \\
\text { Sverdrup Inlet }\end{array}$ & $\begin{array}{c}\text { Second Bay E of } \\
\text { Sverdrup Inlet }\end{array}$ & $\begin{array}{l}\text { Sverdrup } \\
\text { Inlet }\end{array}$ & $\begin{array}{l}\text { Muskox } \\
\text { Fiord }\end{array}$ & $\begin{array}{c}\text { Starnes } \\
\text { Fiord }\end{array}$ \\
\hline Somerset & $96-17000$ & $\mathrm{~F}$ & & 3 & 1 & 1 & & & & & 2 \\
\hline Somerset & $96-17001$ & $\mathrm{~F}$ & & 4 & 1 & & & 3 & & & \\
\hline Somerset & 96-17002 & $\mathrm{F}$ & & 3 & & & & & & & \\
\hline Somerset & $96-17003$ & $\mathrm{~F}$ & 10 & 2 & & 12 & & & & & \\
\hline Somerset & 96-17004 & $\mathrm{F}$ & 4 & & & & & & & & \\
\hline Somerset & 96-17006 & $\mathrm{F}$ & 10 & & & & & & & & \\
\hline Somerset & $96-17007$ & $\mathrm{M}$ & 1 & & & & & & & & \\
\hline Somerset & $96-17008$ & $\mathrm{~F}$ & 5 & 1 & & & & & & & \\
\hline Somerset & $96-17010$ & $\mathrm{M}$ & 9 & 2 & 3 & 1 & & & & & \\
\hline Somerset & $96-17011$ & $\mathrm{M}$ & & & 8 & 3 & 1 & 1 & 1 & & \\
\hline Croker & $96-20683$ & $\mathrm{~F}$ & & 1 & 5 & 4 & & & & & \\
\hline Croker & $96-20684$ & $\mathrm{M}$ & & 2 & 6 & 6 & & & & 1 & \\
\hline Croker & $96-20685$ & $\mathrm{~F}$ & 1 & 3 & 3 & 1 & & & & & \\
\hline Croker & $96-20686$ & $\mathrm{~F}$ & & & 3 & 4 & & & & & \\
\hline Croker & $96-20687$ & $\mathrm{M}$ & 1 & 17 & 2 & 2 & & & & & \\
\hline Croker & $96-20688$ & $\mathrm{M}$ & 10 & 19 & & & & & & & \\
\hline Croker & 96-20689 & $\mathrm{M}$ & & & & & & & & & \\
\hline Croker & $96-20690$ & $\mathrm{~F}$ & 1 & 4 & 2 & & & & & & \\
\hline Croker & $96-20693$ & $\mathrm{~F}$ & 3 & 15 & 4 & 2 & & & & & \\
\hline
\end{tabular}

and Cornwallis Islands (Welch et al., 1993). Belugas may use the deep Franklin Trench in the middle of southern Peel Sound to forage for deepwater prey (Martin and Smith, 1992; Smith and Martin, 1994).

\section{Autumn Movements and Area Use}

All but one of the eight Somerset animals still transmitting moved into Croker Bay between 8 and 21 September before moving farther east (Figs. 6 and 7, Table 4). From the Croker Bay capture camp, belugas were first observed on 2 September, and they were seen as late as 18 September, after which the camp was abandoned. The mean arrival time for belugas tagged at Somerset Island was 15 September. This suggests that the animals we tagged at Croker Bay were early migrants. The occurrence of belugas in or near Croker Bay has been reported by other authors to occur in mid to late September (Renewable Resources 


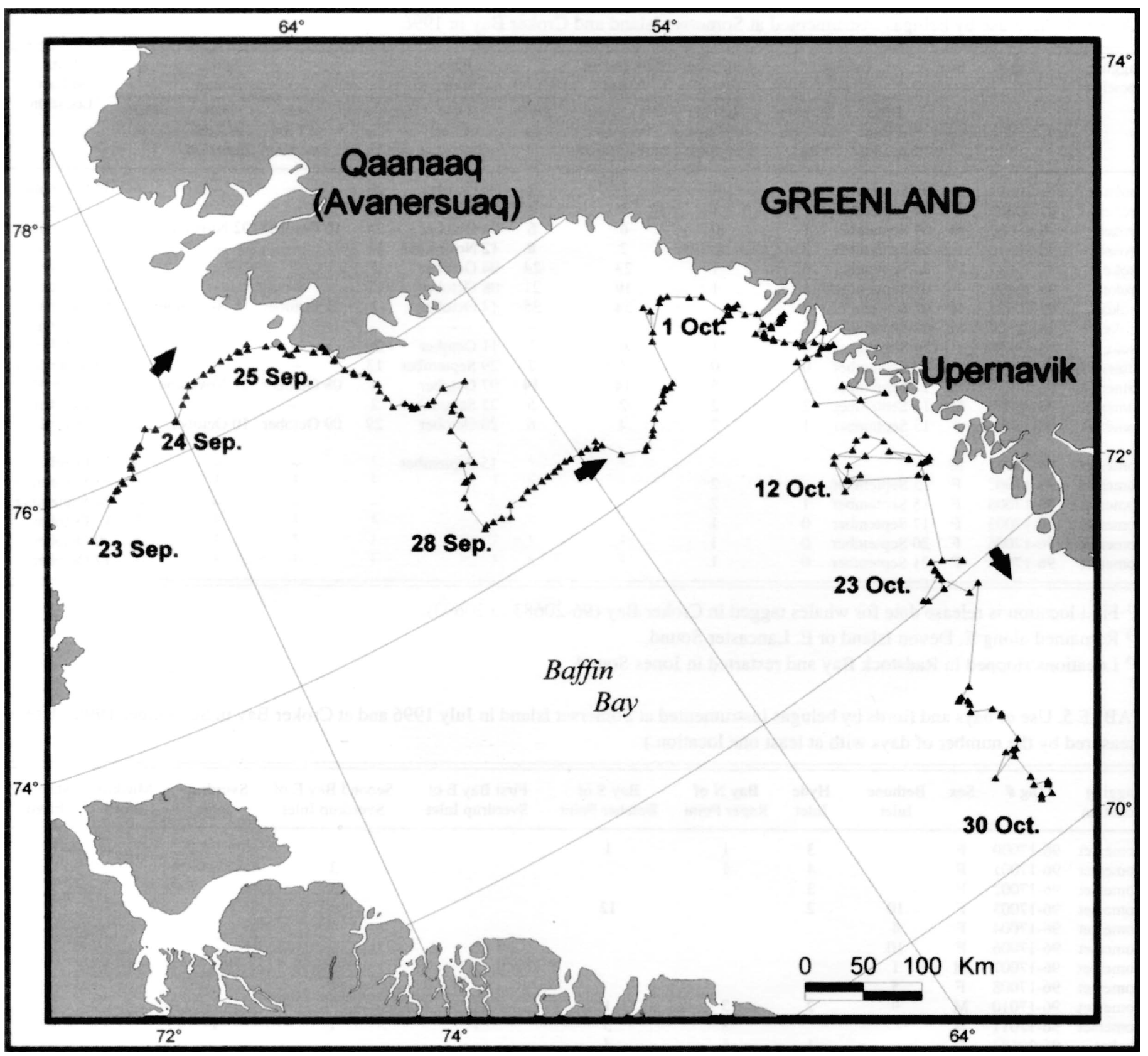

FIG. 8. Movement of male 96-17007 into Greenland waters between 23 September and 30 October.

Consulting Services Ltd., 1976; Davis and Finley, 1979; Reeves and Mitchell, 1987; Smith and Martin, 1994).

Four of the Somerset animals and six belugas newly tagged in Croker Bay moved out of the bay after a few hours (Figs. 6 and 7, Table 4). The rest remained in Croker Bay for 1-5 days. All eighteen belugas continued to migrate eastward in Lancaster Sound after leaving Croker Bay, following the south coast of Devon Island. One (96-17008) stopped giving locations during that time (Table 4). The remainder continued north along the east coast of Devon Island (Figs. 6 and 7) after stops in Bethune Inlet, Hyde Inlet, a bay north of Raper Point, and a bay south of Belcher Point (Figs. 6 and 7, Tables 4 and 5). Four Somerset females remained along the east coast of Devon Island and in eastern Lancaster Sound until their last locations between 23 September and 30 October (Table 4). Male 9617011, whose transmitter stopped giving locations while near Radstock Bay on 7 September, resumed transmissions in Sverdrup Inlet, Jones Sound, a day and a half later. Although the route taken by this individual is unknown, we assume that it followed the same course as the others, since the alternative route into Jones Sound via the west side of Devon Island is longer. The rest of the animals reached the entrance of Jones Sound within 5-8 days after their first location in or near Croker Bay. However, three of them (9620687, 96-20688, and 96-20693) did not enter Jones Sound immediately, remaining along the east coast of Devon Island for 14 to 34 days (Table 4). 


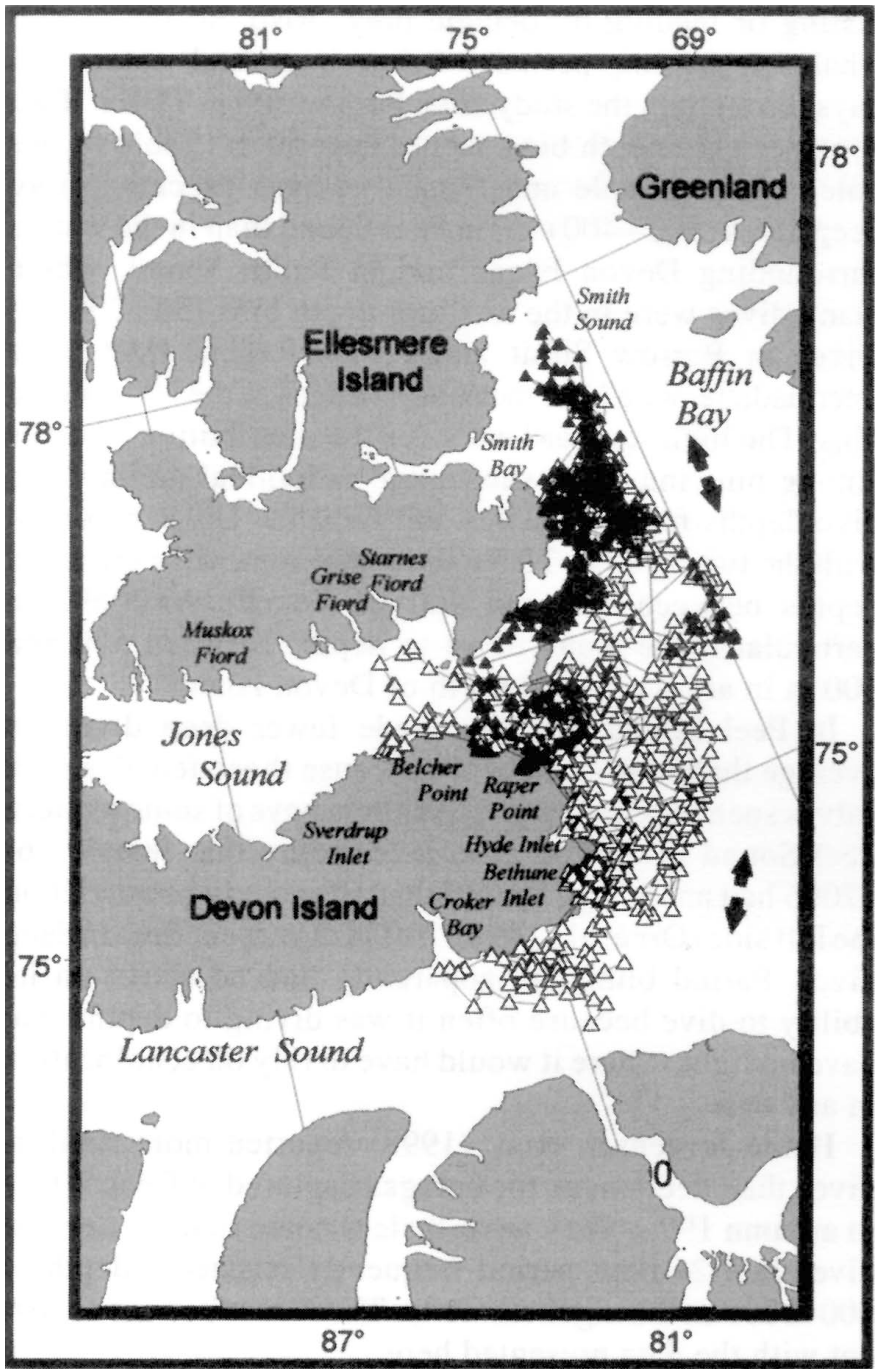

FIG. 9. Movements between 1 October and 1 November of male belugas instrumented at Somerset Island (closed triangles) and Croker Bay (open triangles).

Activity in late September centred in Jones Sound, Lady Ann Strait, and bays and coastal areas of eastern Devon Island (Figs. 6 and 7). One exception was male 9617007, tagged at Creswell Bay, Somerset Island. After a few days in Jones Sound, this animal started moving eastward and reached Greenland waters on 24 September (Fig. 8). It remained on the Greenland side of Baffin Bay until its last location on 30 October (see below, Stock Identity). By early October, the other tagged belugas started spending less time in bays of eastern Devon Island and moved farther offshore into Baffin Bay, and into Smith Sound or back into Lancaster Sound, areas which they occupied until they stopped transmitting in late October or November (Figs. 9-11). Three males and one female occupied Smith Sound (Table 4). This is the first report of a female using Smith Sound. Richard et al. (1998b) reported that, of the whales they tagged in 1995, only the males used Smith Sound. Use of Jones Sound continued into late October and November. The last positions of the tagged belugas whose tags were still transmit-

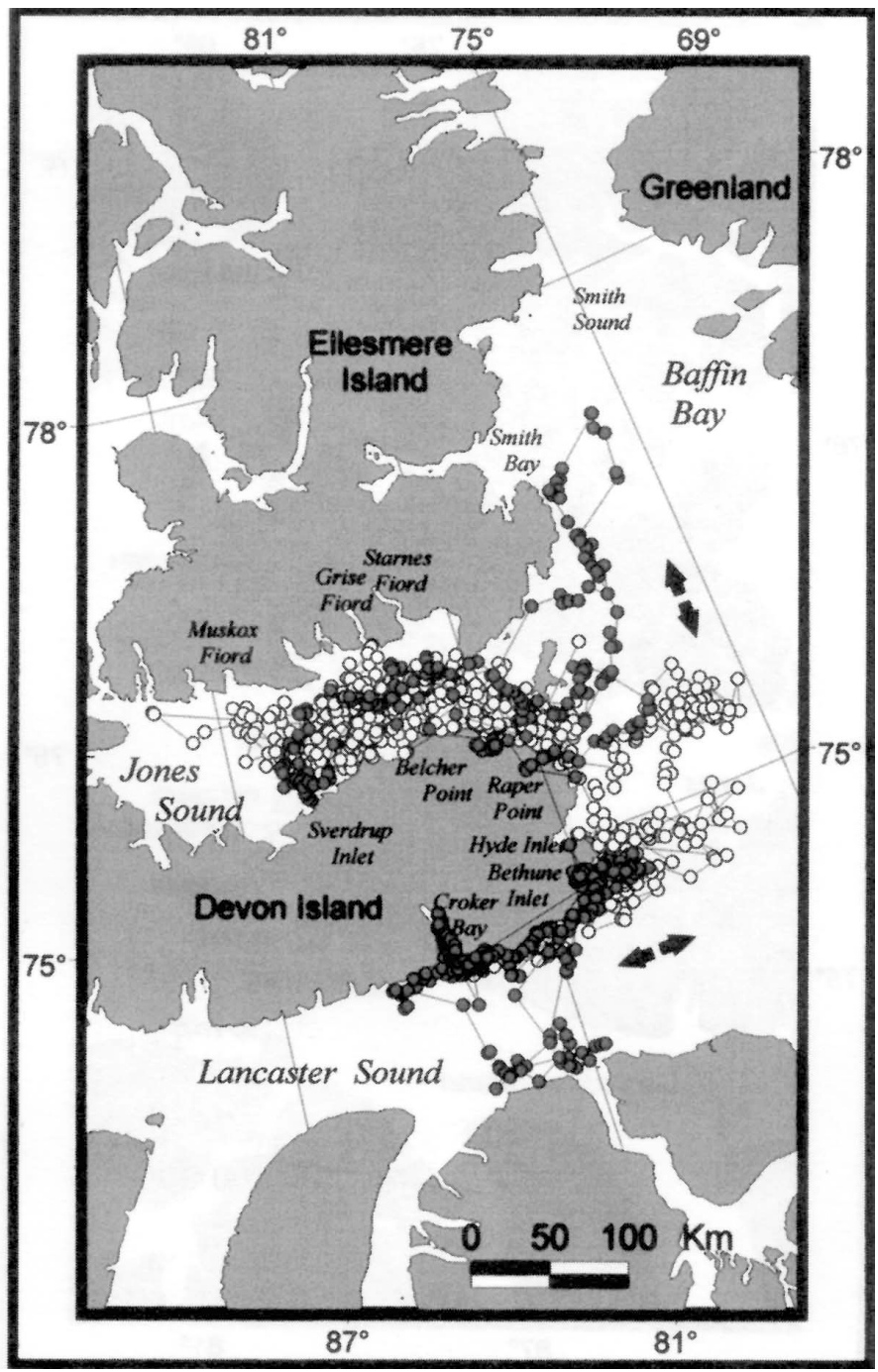

FIG. 10. Movements between 1 October and 1 November of female belugas instrumented at Somerset Island (closed circles) and Croker Bay (open circles).

ting after 10 October (Fig. 11) suggest that males are more prone to use the northern portion of the North Water area than females, as was reported for the belugas tagged in 1995 (Richard et al., 1998b).

During the autumn period, all of the tagged belugas occupied bays along eastern Devon Island and southern Ellesmere Island (Tables 4 and 5). Those used most frequently were Croker Bay (Table 4) and the bays along eastern Devon Island: Bethune Inlet, Hyde Inlet, and the two unnamed bays between Raper Point and Belcher Point (Table 5). Croker Bay was frequented by the most animals (16 of 18; Table 4), whereas Hyde Inlet was frequented for the longest time (mean $=5.4$ days, range $=1-19$ days; Table 5). These bays were used most frequently in September but some were also revisited in October.

The occupation of these bays was also documented by Davis and Finley (1979), Koski and Davis (1979, 1980), and Richard et al. (1998b) but it remains unclear why they are used. The skin moult is finished by September and these bays are all glacier-fed and therefore do not have the 


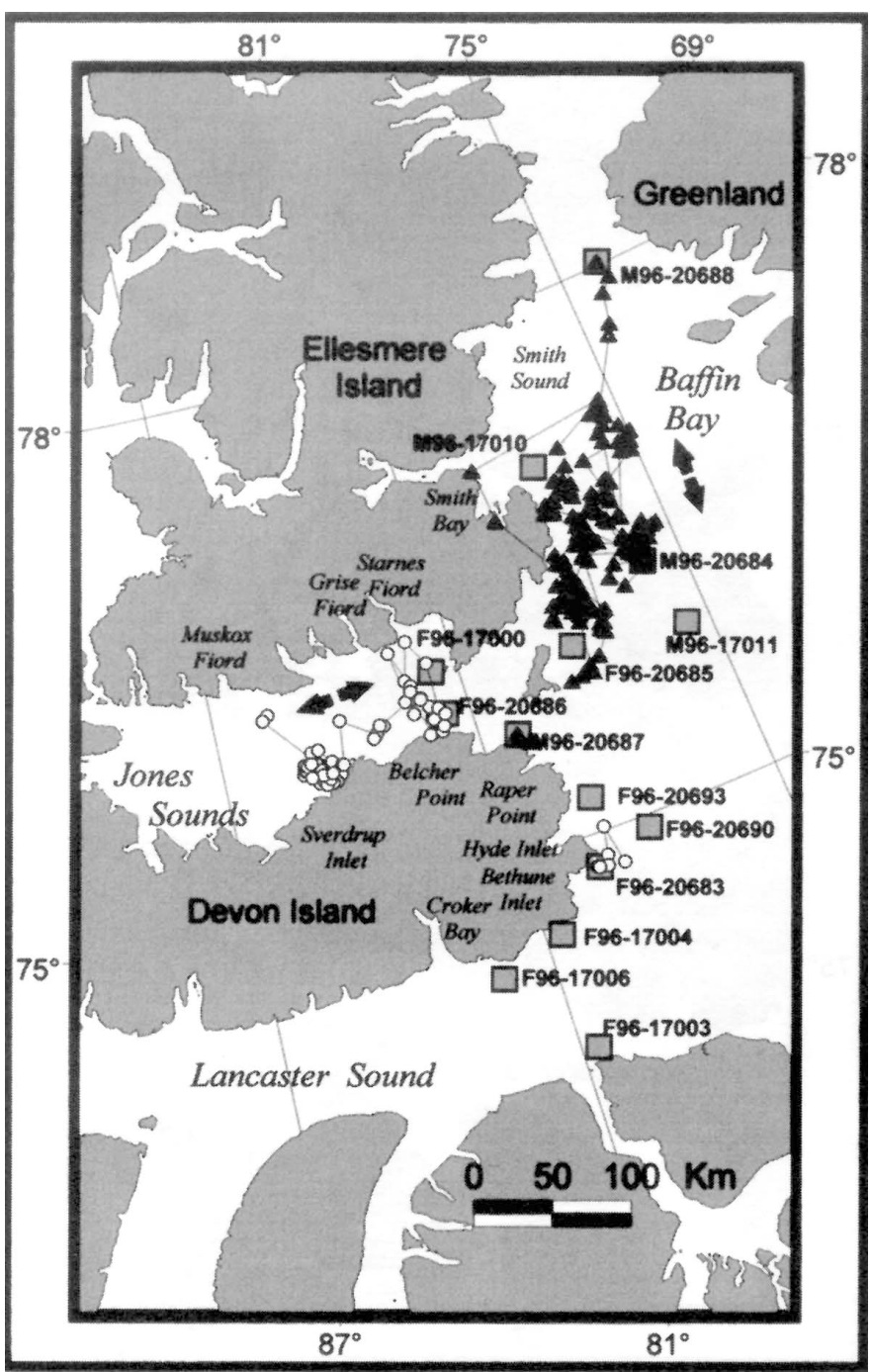

FIG. 11. November movements and last locations of tagged belugas that gave locations after 10 October. Triangles are males and circles are females. Grey squares represent their last locations.

relatively warm water that is hypothesized to promote skin moult (St. Aubin et al., 1990). Occupation of the bays and the adjacent coastal areas could be related to the presence of arctic cod (Boreogadus saida), which occur in large schools near shore in the autumn (Bradstreet et al., 1986; Welch et al., 1993; Richard et al., 1998b). In deep bays such as Croker Bay, other prey such as Greenland halibut (Reinhardtius hippoglossoides) and squid (Gonatus fabricii) may also be sought (Richard et al., 1998b).

\section{Dive Depth in Relation to Area}

The results of dive depth (bin) proportions are presented separately for time-depth recorders (TDRs) with dynamic range to $500 \mathrm{~m}$ (Table 6) and to $1000 \mathrm{~m}$ (Table 7). In both cases, the proportion of dives in the "less than $50 \mathrm{~m}$ " bin was high in all areas. This result would be expected, since the whales must have spent a portion of each 6-hour sampling period in shallow dives, while resting or feeding on pelagic prey. Also, all the tagged whales spent long periods of time in coastal waters and bays throughout the study area. For the $500 \mathrm{~m}$ TDRs, if we consider only depth bins deeper than $50 \mathrm{~m}$ (Table 6), we note that both male and female belugas executed more deep dives $(300-400+m)$ in Peel Sound than in the waters surrounding Devon Island and in Smith Sound, where many dives were in the medium-depth bins $(50-200 \mathrm{~m})$. Dives in Barrow Strait and Prince Regent Inlet were intermediate, with high mean proportions in the $200-400 \mathrm{~m}$ bins. The high standard error for the distribution of dives among bins indicated substantial individual variation in dive depths for both males and females. Dives recorded with the two $1000 \mathrm{~m}$ TDRs show that some dives reached depths between 500 and $900 \mathrm{~m}$. Female 96-20690 in particular made many dives to depths between 500 and $600 \mathrm{~m}$ in areas east and north of Devon Island.

In Peel Sound, females made fewer deep dives on average than males, probably because those females with calves spent more time in the shallow bays of southwestern Peel Sound (Table 3). It is noteworthy that female 9617006 had an old eye wound that effectively blinded it on the left side (Orr et al., 1998). Yet, it also spent time in deep dives. Partial blindness apparently had no effect on its ability to dive because often it was diving to depths that have no light, where it would have to rely on echolocation in any case.

Heide-Jørgensen et al. (1998) reported more shallow dives than deep dives for belugas captured at Croker Bay in autumn 1995. They nevertheless noted that the deepest dives in a 24-hour period frequently reached a depth of 400-800+ $\mathrm{m}$ during their study. These results are consistent with the data presented here.

It is unknown why belugas occasionally dive to the depths that they do. Shallow dives may be related to feeding on pelagic species such as arctic cod. When diving to $400-800+\mathrm{m}$, belugas may be seeking deepwater prey, such as Greenland halibut or squid (Richard et al., 1998b).

\section{Swimming Speeds}

Swimming speeds varied considerably during the study period, but there was no obvious trend over time. A general linear model of the $\log$ (speed) with independent variables $\log$ (time) and beluga Tag ID showed no significant difference over time $(p=0.8103)$ but significant differences for individual belugas $(p=0.0000)$. All but one beluga exhibited swimming speeds of more than $9 \mathrm{~km} / \mathrm{hr}$. Most of them occasionally reached speeds between 10 and $20 \mathrm{~km} / \mathrm{hr}$. The overall average swimming speed for animals with 30 or more measurements (i.e., excluding females 96-20685 and 96-20693 and male 96-20689) was $3.98 \mathrm{~km} / \mathrm{hr}(\mathrm{n}=3142$, $\mathrm{SD}=2.90)$. Individual averages of those samples ranged between 2.64 and $5.00 \mathrm{~km} / \mathrm{hr}$. There is no indication that average speed is related to body size since it did not vary significantly with whale length $(p=0.252946)$. 
TABLE 6. Percentage of dives in depth bins by sector of the study area, measured from belugas equipped with $500 \mathrm{~m}$ time-depth recorders. Shading indicates heightened activity ( $5 \%$ or more) in bins deeper than $0-50 \mathrm{~m}, 0 \%$ were blanked out.

\begin{tabular}{|c|c|c|c|c|c|c|c|c|c|c|c|c|c|c|}
\hline \multirow[t]{3}{*}{ Area/Sex (\# indiv.) } & \multicolumn{2}{|c|}{ \# samples } & \multicolumn{12}{|c|}{$\%$ Dives to } \\
\hline & \multirow[b]{2}{*}{ Mean } & \multirow[b]{2}{*}{$(\mathrm{SD})$} & \multicolumn{2}{|c|}{$<50 \mathrm{~m}$} & \multicolumn{2}{|c|}{$50-100 \mathrm{~m}$} & \multicolumn{2}{|c|}{$100-200 \mathrm{~m}$} & \multicolumn{2}{|c|}{$200-300 \mathrm{~m}$} & \multicolumn{2}{|c|}{$300-400 \mathrm{~m}$} & \multicolumn{2}{|c|}{$400+m$} \\
\hline & & & Mean & (SD) & Mean & (SD) & Mean & (SD) & Mean & (SD) & Mean & $(\mathrm{SD})$ & Mean & (SD) \\
\hline \multicolumn{15}{|l|}{ Barrow Strait } \\
\hline $\mathrm{F}(8)$ & 62 & $(45)$ & 85.3 & (19.7) & 1.9 & $(5.9)$ & 1.8 & $(5.2)$ & 6.1 & $(13.7)$ & 4.9 & $(14.2)$ & & \\
\hline M (3) & 70 & $(12)$ & 78.9 & $(33.2)$ & 1.0 & $(2.3)$ & 0.5 & $(1.4)$ & 3.6 & $(12.4)$ & 8.7 & $(21.5)$ & 7.2 & $(20.8)$ \\
\hline All (11) & 65 & $(37)$ & 83.3 & $(24.8)$ & 1.6 & $(5.0)$ & 1.4 & $(4.4)$ & 5.3 & $(13.3)$ & 6.1 & $(16.8)$ & 2.2 & $(12.0)$ \\
\hline \multicolumn{15}{|c|}{ Prince Regent Inlet } \\
\hline $\mathrm{F}(5)$ & 82 & $(67)$ & 79.4 & $(30.5)$ & 1.4 & $(4.8)$ & 0.4 & (1.4) & 7.8 & (18.9) & 10.4 & (21.5) & 0.5 & $(2.7)$ \\
\hline M (3) & 39 & (9) & 90.5 & (17.7) & 0.5 & (1.2) & 0.4 & $(2.3)$ & 0.4 & $(1.8)$ & 6.1 & (14.4) & 2.1 & (7.3) \\
\hline All (8) & 66 & $(56)$ & 81.9 & (28.5) & 1.2 & (4.3) & 0.4 & (1.6) & 6.2 & (17.0) & 9.5 & (20.2) & 0.9 & $(4.2)$ \\
\hline \multicolumn{15}{|l|}{ N Peel Sound } \\
\hline $\mathrm{F}(8)$ & 81 & (54) & 75.8 & (25.6) & 1.3 & $(4.0)$ & 1.3 & $(6.0)$ & 3.2 & $(7.8)$ & 13.8 & $(22.5)$ & 4.5 & $(13.0)$ \\
\hline M (3) & 113 & $(70)$ & 66.6 & (29.3) & 0.4 & (1.6) & 0.2 & (1.0) & 1.9 & (6.9) & 15.3 & (24.7) & 15.6 & $(22.7)$ \\
\hline All (11) & 89 & $(57)$ & 72.6 & $(27.3)$ & 1.0 & $(3.4)$ & 1.0 & $(4.9)$ & 2.7 & $(7.5)$ & 14.4 & (23.3) & 8.3 & (17.7) \\
\hline \multicolumn{15}{|l|}{ S Peel Sound } \\
\hline $\mathrm{F}(8)$ & 433 & (157) & 75.6 & $(26.0)$ & 0.5 & $(4.2)$ & 0.2 & $(1.2)$ & 2.2 & $(7.8)$ & 11.1 & (19.0) & 10.5 & $(17.0)$ \\
\hline M (3) & 209 & $(72)$ & 59.5 & $(32.0)$ & 0.3 & (1.6) & 0.3 & $(1.5)$ & 1.2 & $(5.7)$ & 16.4 & (26.0) & 22.4 & (26.3) \\
\hline All (11) & 372 & (171) & 73.1 & (27.6) & 0.5 & $(3.9)$ & 0.2 & $(1.2)$ & 2.0 & $(7.5)$ & 11.9 & (20.3) & 12.3 & $(19.2)$ \\
\hline \multicolumn{15}{|l|}{ Lancaster Sound } \\
\hline $\mathrm{F}(11)$ & 71 & $(47)$ & 87.7 & (17.4) & 6.1 & $(10.5)$ & 3.0 & $(8.6)$ & 1.3 & $(4.2)$ & 1.4 & $(4.7)$ & 0.6 & $(2.9)$ \\
\hline M (4) & 111 & $(91)$ & 90.5 & $(13.6)$ & 5.6 & $(8.5)$ & 2.2 & $(4.3)$ & 0.6 & $(3.0)$ & 1.1 & $(6.5)$ & & \\
\hline All (15) & 82 & $(61)$ & 88.7 & $(16.2)$ & 5.9 & $(9.8)$ & 2.7 & (7.4) & 1.0 & (3.9) & 1.3 & $(5.4)$ & 0.4 & $(2.4)$ \\
\hline \multicolumn{15}{|c|}{ E Devon Island - Lady Ann Strait } \\
\hline $\mathrm{F}(11)$ & 110 & $(89)$ & 78.9 & (19.5) & 5.4 & (11.0) & 5.5 & $(10.7)$ & 2.9 & $(6.9)$ & 2.9 & $(7.7)$ & 4.3 & $(8.4)$ \\
\hline$M(5)$ & 231 & $(92)$ & 84.2 & (19.2) & 4.0 & $(7.3)$ & 7.5 & (13.3) & 3.2 & (11.6) & 0.3 & (1.9) & 0.8 & $(2.7)$ \\
\hline All (16) & 278 & $(547)$ & 81.5 & (19.5) & 4.8 & $(9.4)$ & 6.5 & (12.1) & 3.1 & $(9.5)$ & 1.6 & $(5.8)$ & 2.6 & $(6.6)$ \\
\hline \multicolumn{15}{|l|}{ Jones Sound } \\
\hline $\mathrm{F}(6)$ & 171 & (117) & 80.8 & (19.9) & 5.0 & $(9.2)$ & 5.1 & $(10.3)$ & 2.9 & $(7.5)$ & 2.2 & $(6.7)$ & 4.2 & $(8.7)$ \\
\hline M (5) & 50 & $(58)$ & 92.6 & (10.4) & 1.9 & $(3.4)$ & 2.9 & $(6.3)$ & 1.6 & $(6.7)$ & 0.3 & $(1.4)$ & 0.7 & $(2.1)$ \\
\hline All (11) & 213 & (111) & 83.1 & (19.0) & 4.4 & $(8.5)$ & 4.7 & $(9.7)$ & 2.6 & (7.4) & 1.8 & $(6.1)$ & 3.5 & $(8.0)$ \\
\hline \multicolumn{15}{|l|}{ Smith Sound } \\
\hline $\mathrm{F}(2)$ & 15 & (19) & 84.0 & (13.6) & 5.4 & $(4.3)$ & 5.6 & $(7.2)$ & 3.9 & (7.1) & 0.6 & $(2.2)$ & 0.5 & $(2.3)$ \\
\hline M (4) & 139 & (214) & 74.9 & (17.5) & 6.2 & $(9.7)$ & 11.1 & (12.8) & 4.0 & $(9.1)$ & 2.5 & (7.9) & 1.3 & $(4.5)$ \\
\hline All (6) & 98 & $(150)$ & 75.3 & (17.5) & 6.1 & $(9.5)$ & 10.8 & (12.6) & 4.0 & $(9.0)$ & 2.4 & $(7.8)$ & 1.3 & $(4.4)$ \\
\hline
\end{tabular}

Smith and Martin (1994) reported much lower average swimming speeds $(1.1-1.85 \mathrm{~km} / \mathrm{hr})$ for belugas tagged at Somerset Island but cautioned that these were "conservative" (i.e., negatively biased) estimates based on few data. Their calculations were based only on locations separated in time by at least 5 hours. Such estimates of swimming speeds suffer from a negative bias when measuring distance travelled from a line between two locations rather than from the path that the animal actually travels. Nevertheless, Smith and Martin (1994) did note that one migrating female in their study had an average speed of $5.99 \mathrm{~km} /$ hr for a few days. We calculated averages using shorter intervals between locations $(0.5-2 \mathrm{hr})$, and therefore our estimates of swimming speeds are probably less biased by meandering movements or reversals in direction. Furthermore, we had more data for calculating average speeds because the half-watt transmitters used in our study provided more high-quality locations than the quarter-watt transmitters used by Smith and Martin.

\section{Implications of Movements to Stock Identity}

The present results, added to those from the six belugas tagged at Croker Bay in September 1995 (Richard et al., 1998b), give a total of 16 belugas tagged at Somerset
Island and Croker Bay that gave locations well into October (after 10 October) and five more that gave locations into November. Belugas are normally observed and hunted along the coast of northwest Greenland in September and October (Thomsen, 1993), and most beluga hunting occurs between 15 and 23 September in the Qaanaaq (formerly Avanersuaq) area, and between 25 September and 5 October in the Upernavik area (Heide-Jørgensen, unpubl. data). This migration peak was previously assumed to consist of the largest portion of the Baffin Bay "stock" that moved from the Canadian High Arctic to wintering areas off central West Greenland (Doidge and Finley, 1993; HeideJørgensen, 1994). Yet, contrary to expectations, only one of our tagged belugas (Creswell Bay male 96-17007) migrated to West Greenland. The remaining 20 belugas stayed in the area known in the winter as the North Water. This area has recurring leads and polynyas throughout winter (Smith and Rigby, 1981), and belugas are known to spend the winter there (Freeman, 1968, 1973; Finley and Renaud, 1980; Richard et al., 1998a).

There are two possible explanations for these results. One is that many more belugas remain in the North Water for the winter than was previously assumed. Another is that the southward autumn migration along the Greenland coast observed by Qaanaaq, Upernavik, and Uumaannaq 


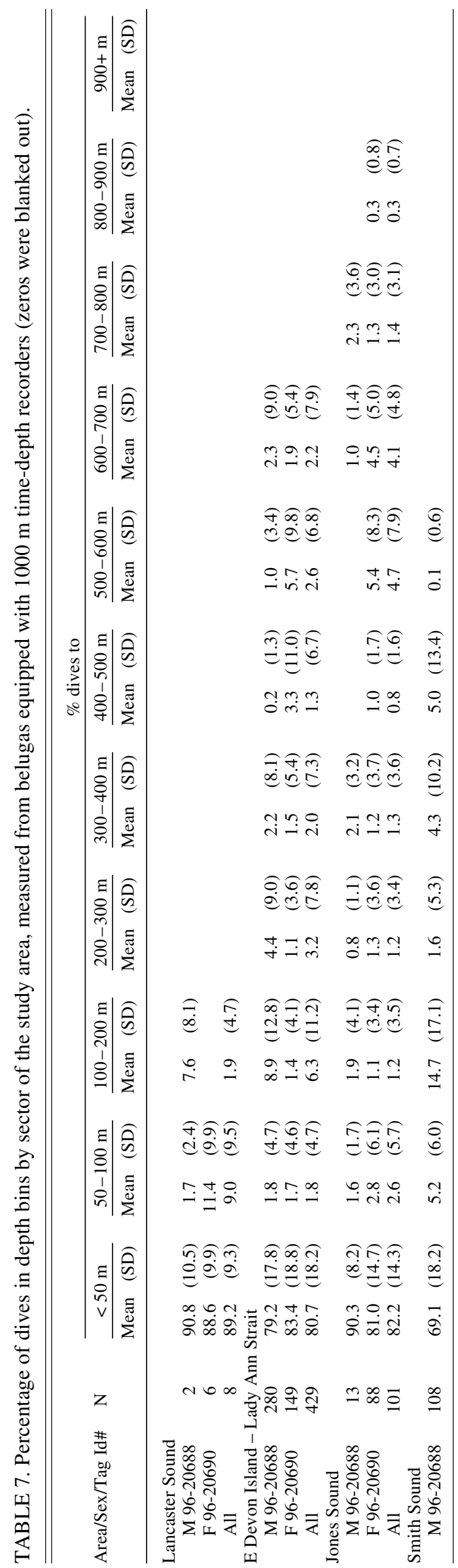

residents in late September or early October is not the only migration to the West Greenland wintering area. A second migration to Greenland waters could occur later on, in early winter, but go unnoticed by Greenlanders because it takes place during the dark season or farther offshore.

Several potential sources of bias may affect the extrapolation of our tracking results to the entire Baffin Bay population. First, the periods of capture and the areas used as sites for live-capture may not provide a random selection of the stock. Second, we avoided capturing small belugas because, from previous experience, we thought the tags would not hold as long on smaller animals. Third, we were unable to catch males in equal numbers to females. Fourth, we captured only a few animals at each site. Finally, it is possible that "naïve" belugas (i.e., those never or rarely exposed to hunting) were more easily captured than experienced ones.

Despite these potential biases, we believe that one of the above explanations is plausible: more High Arctic belugas remain in the North Water in winter than was previously thought (Finley and Renaud, 1980). There are several reasons to believe this hypothesis. First, genetic analyses indicate that most belugas sampled in the High Arctic in summer and fall are different from those taken off West Greenland in winter (B. de March, Fisheries and Oceans, Winnipeg, pers. comm. 2000). Second, even if only a few hundred belugas have been sighted there during winter surveys (Finley and Renaud, 1980; Richard et al., 1998b), the North Water could in fact harbour several thousand belugas. The surveys may not have covered the entire area that belugas occupy. They focused mostly on the leads and polynyas and thus are not adequate to estimate total population size. Counts were not corrected for submerged whales or those missed by observers. Numbers of belugas could therefore be grossly underestimated because the animals are particularly hard to count in ice-covered waters. In addition, Heide-Jørgensen et al. (1998) observed that tagged belugas in the North Water spent on average only about $30 \%$ of their time in the surface layers during the late autumn. Similar results were obtained with the whales tagged in 1996 (HeideJørgensen et al., 2001). Finally, survey observers are also likely to miss half of the numbers available at the surface in ice (Heide-Jørgensen, unpubl. data). This proportion may be even larger in the North Water because the severe ice conditions make counting very difficult. Therefore, it is probable that the North Water is inhabited in winter by many more belugas than the uncorrected counts during March and April surveys indicate.

Two questions remain. Was our sample of adult belugas representative of the migratory movements of all belugas that summer in the Canadian High Arctic? And does the small proportion of tagged belugas moving to West Greenland reflect overall population movements? It is likely, given the small number of animals we tagged, that there is a segment of the summer population that was not adequately sampled. Future research should attempt to increase the sample size in the estuaries already sampled and to extend the tagging effort to other aggregation areas.

\section{CONCLUSIONS}

We have described the behaviour of a small sample of animals from a population of belugas numbering in the thousands. This small and probably biased sample of tagged belugas may not allow generalization to the entire population, but the results, which are very similar to those 
of Smith and Martin (1994), probably describe the behaviour of a substantial portion of the Canadian High Arctic beluga stock. Tagged belugas from the three major estuarine aggregations of Somerset Island spent little time in the estuaries proper in July. Most moved rapidly to southern Peel Sound and spent the month of August there. While in the Sound, they approached the coast of Prince of Wales Island, going near and into Coningham Bay, and made forays to the middle of the sound, where they dove to depths near or at the seabed of the Franklin Trench, probably in pursuit of some deepwater prey. Some belugas used Bellot Strait to get to Peel Sound. All belugas used three other bays (Transition Bay, Willis Bay, and Strzelecki Harbor) along the coast of Prince of Wales Island, and a few used Wrottesley Bay on the Melville Peninsula. In some bays, the belugas occupied the estuaries of small rivers. The belugas left southern Peel Sound from late August to early September and moved rapidly to the coast of Devon Island, many using Maxwell Bay for a period of time. They may be attracted to the coastal areas of south Devon Island and, in some cases, Cornwallis Island, by the large schools of arctic cod that congregate in these areas in the fall. The beluga tracks confirmed that the migration route of belugas summering around Somerset Island is close to the southern shore of Devon Island and that migration peaks around mid-September (Koski and Davis, 1980; Smith and Martin, 1994). Tagged belugas visited fjords and bays along the southern, eastern, and northeastern coasts of Devon Island in September and October. They also occupied the neighbouring offshore waters, where they mostly made dives to depths of $200 \mathrm{~m}$ or less, but also some dives that reached the seabed depths in the area $(400-800+m)$. Furthermore, we conclude from this study that a larger number of belugas must remain in the North Water for the winter than was previously believed.

This study raises new questions for future research, including the following:

1. What are belugas feeding on in the Franklin Trench? Why is this area apparently so important to them?

2. Why do they apparently make short feeding excursions in the Franklin Trench, then return to the coast, rather than remaining in the feeding area all the time?

3. Why do belugas visit bays of Devon and Ellesmere Islands during their autumn migration?

4. Is there a large segment of the summering population that migrates to Greenland that has not yet been sampled?

5. Is there an early winter migration from the North Water to West Greenland waters?

The extensive use documented here of the deep Franklin Trench, and of the coastlines and bays of southern Peel Sound, Barrow Strait, and Lancaster Sound, should be considered in the planning of future assessment surveys. Studies focusing on prey selection in those areas are needed to determine the place of Canadian High Arctic belugas in the food web and the pathways of contaminant bioaccumulation. The results are important for ocean conservation planning, for coastal zone management, for environmental impact assessments of oil and gas and mining development, and for shipping activities in the study area. Finally, it is significant to note the range of movement of these belugas, which indicates that they are not easily accessible to Inuit communities most of the year. This fact could explain why catches of belugas in the Canadian High Arctic are low compared to those in other areas of the Canadian Arctic.

\section{ACKNOWLEDGEMENTS}

This paper is dedicated to the late Stuart Innes, who saw the value of tracking and time-depth recording for aerial survey interpretation and secured a good portion of the funding for the summer portion of this study. We are most grateful to J. Akeeagok, J. Boehm, J. Dancosse, S. Deguise, H. Gordon, O. Iqaluk, C. Kalluk, D. Pike, S. Qamarniq, D. St. Aubin, R. Suydam, and C. Wright for their diligence in the field. We are indebted to the Polar Continental Shelf Project and First Air for their logistical support. We thank the Resolute, Grise Fiord, Arctic Bay, and Pond Inlet Hunters and Trappers Organizations for their support and interest. The Greenland Institute of Natural Resources, the Commission for Scientific Research in Greenland, the Danish National Environmental Research Institute, the Nunavut Wildlife Management Board, and the Department of Fisheries and Oceans funded this project. Magali Baratin helped in the analysis of the dive data. We thank R. Reeves, D. St. Aubin, and two anonymous reviewers for their comments on earlier drafts.

\section{REFERENCES}

ARGOS. 1996. Users manual ver. 1. Toulouse, France: CLS ARGOS. BRADSTREET, M.S.W., FINLEY, K.J., SEKERAK, A.D., GRIFFITHS, W.B., EVANS, C.R., FABIJAN, M.F., and STALLARD, H.E. 1986. Aspects of the biology of arctic cod (Boreogadus saida) and its importance in Arctic marine food chains. Canadian Technical Report of Fisheries and Aquatic Sciences 1491. $193 \mathrm{p}$.

CARON, L.M.J., and SMITH, T.G. 1990. Philopatry and site tenacity of belugas, Delphinapterus leucas, hunted by the Inuit at the Nastapoka estuary, eastern Hudson Bay. In: Smith, T.G., St. Aubin, D.J., and Geraci, J.R., eds. Advances in research on the beluga whale, Delphinapterus leucas. Canadian Bulletin of Fisheries and Aquatic Sciences 224. 69-79.

DAVIS, R., and FINLEY, K.J. 1979. Distribution, migrations, abundance, and stock identity of Eastern Arctic white whales. International Whaling Commission Scientific Committee Document SC/31/SM10. 44 p.

DOIDGE, D.W. 1990. Age-length and length-weight comparisons in the beluga, Delphinapterus leucas. In: Smith, T.G., St. Aubin, D.J., and Geraci, J.R., eds. Advances in research on the beluga whale, Delphinapterus leucas. Canadian Bulletin of Fisheries and Aquatic Sciences 224. 59-68. 
DOIDGE, D.W., and FINLEY, K.J. 1993. Status of the Baffin Bay population of beluga, Delphinapterus leucas. Canadian FieldNaturalist 107:533-546.

FINLEY, K.J., and JOHNSON, W.G. 1977. An investigation of the distribution of marine mammals in the vicinity of Somerset Island with emphasis on Bellot Strait, August-September 1976 by LGL Limited, Environmental Research Associates. Unpubl. report to Polar Gas Project, King City, Ont. 37 p. Available from DFO, Freshwater Institute, 501 University Crescent, Winnipeg, Manitoba R3T 2N6.

FINLEY, K.J., and RENAUD, W.E. 1980. Marine mammals inhabiting the Baffin Bay North Water in winter. Arctic 33(4):724-738.

FREEMAN, M.M.R. 1968. Winter observations on beluga (Delphinapterus leucas) in Jones Sound, N.W.T. Canadian Field-Naturalist 82:276-286.

- 1973. Polar bear predation on beluga in the Canadian Arctic. Arctic 26(2):162-163.

HEIDE-JØRGENSEN, M.P. 1994. Distribution, exploitation and population status of white whales (Delphinapterus leucas) and narwhals (Monodon monoceros) in West Greenland. Meddelelser om Grønland, Bioscience 39:135-149.

HEIDE-JØRGENSEN, M.P., and REEVES, R.R. 1996. Evidence of a decline in beluga, Delphinapterus leucas, abundance off West Greenland. International Convention for the Exploration of the Seas Journal of Marine Science 53:61-72.

HEIDE-JØRGENSEN, M.P., and TEILMANN, J. 1994. Growth, reproduction, age structure and feeding habits of white whales (Delphinapterus leucas) in West Greenland waters. Meddelelser om Grønland, Bioscience 39:195-212.

HEIDE-JØRGENSEN, M.P., LASSEN, H., and TEILMANN, J. 1993. An index of the relative abundance of wintering belugas, Delphinapterus leucas, and narwhals, Monodon monoceros, off West Greenland. Canadian Journal of Fisheries and Aquatic Sciences 50:2323-2335.

HEIDE-JØRGENSEN, M.P., DIETZ, R., and LEATHERWOOD, S. 1994. A note on the diet of narwhals (Monodon monoceros) in Inglefield Bredning (NW Greenland). Meddelelser om Grønland, Bioscience 39:213-216.

HEIDE-JØRGENSEN, M.P., RICHARD, P.R., and ROSINGASVID, A. 1998. Dive patterns of belugas (Delphinapterus leucas) in waters near eastern Devon Island. Arctic 51(1):17-26.

HEIDE-JØRGENSEN, M.P., DIETZ, R., ORR, J.R., and RICHARD, P.R. 2001. Surfacing times and dive rates for narwhals (Monodon monoceros) and belugas (Delphinapterus leucas). Arctic 54(3):284-298.

JCCM. 1995. Report of the Joint Commission on Conservation and Management of Narwhal and Beluga. 45 p. Available at DFO, 200 Kent Street, Ottawa, Ontario K1A 0E6.

KOSKI, W.R., and DAVIS, R.A. 1979. Distribution of marine mammals in NW Baffin Bay and adjacent waters, May-October 1978. Report by LGL Ltd., Toronto for Petro-Canada Explorations Ltd., Calgary. Eastern Arctic Environmental Studies (EAMES) Report EN11. 304 p.

1980. Studies of the late summer distribution and fall migration of marine mammals in NW Baffin Bay and ELancaster
Sound, 1979. Report by LGL Ltd., Toronto for Petro-Canada Explorations Ltd., Calgary. EAMES Report EN 13. 305 p.

MALING, D.H. 1989. Measuring from maps: Principles and methods of cartometry. Oxford: Pergamon Press. 577 p.

1993. Coordinate systems and map projections. 2nd ed. Oxford: Pergamon Press. 476 p.

MARKHAM, W.E. 1981. Ice atlas: Canadian Arctic waterways. Ottawa: Atmospheric Environment Service, Environment Canada. 198 p.

MARTIN, A.R., and SMITH, T.G. 1992. Deep diving in wild, freeranging beluga whales, Delphinapterus leucas. Canadian Journal of Fisheries and Aquatic Science 49:462-466.

ORR, J.R., ST. AUBIN, D.J., RICHARD, P.R., and HEIDEJØRGENSEN, M.P. 1998. Recapture of belugas, Delphinapterus leucas, tagged in the Canadian Arctic. Marine Mammal Science 14:829-834.

ORR, J.R., JOE, R., and EVIC, D. 2001. Capturing and handling of white whales (Delphinapterus leucas) in the Canadian Arctic for instrumentation and release. Arctic 54(3):299-304.

REEVES, R.R., and MITCHELL, E. 1987. Distribution and migration, and former abundance of white whales (Delphinapterus leucas) in Baffin Bay and adjacent waters. Canadian Special Publication of Fisheries and Aquatic Sciences 99. 34 p.

RENEWABLE RESOURCES CONSULTING SERVICES LTD. 1976. Aerial Surveys of marine mammals of Lancaster Sound, 1975-1976. Unpubl. report to Norlands Petroleum Ltd. 100 p.

RICHARD, P.R., ORR, J.R., DIETZ, R., and DUECK, L. 1998a. Sightings of belugas and other marine mammals in the North Water, late March 1993. Arctic 51(1):1-4.

RICHARD, P.R., HEIDE-JØRGENSEN, M.P., and ST. AUBIN, D. 1998b. Fall movements of belugas (Delphinapterus leucas) with satellite-linked transmitters in Lancaster Sound, Jones Sound, and northern Baffin Bay. Arctic 51(1):5-16.

SMITH, M., and RIGBY, B. 1981. Distribution of polynyas in the Canadian Arctic. In: Stirling, I., and Cleator, H., eds. Polynyas in the Canadian Arctic. Canadian Wildlife Occasional Paper 45. $7-28$.

SMITH, T.G., and MARTIN, A.R. 1994. Distribution and movements of belugas, Delphinapterus leucas, in the Canadian High Arctic. Canadian Journal of Fisheries and Aquatic Science 51:1653-1663.

ST. AUBIN, D.J., SMITH, T.G. and GERACI, J.R. 1990. Seasonal epidermal molt in beluga whales, Delphinapterus leucas. Canadian Journal of Zoology 68:359-367.

STEWART, R.E.A. 1994. Size-at-age relationships as discriminators of white whale (Delphinapterus leucas) stocks in the eastern Canadian Arctic. Meddelelser om Grønland, Bioscience 39:217-226.

THOMSEN, M.L. 1993. Local knowledge of the distribution, biology, and hunting of beluga and narwhal. A survey among Inuit hunters in West and North Greenland. Nuuk, Greenland: Inuit Circumpolar Conference. 98 p.

WELCH, H.E., CRAWFORD, R.E., and HOP, H. 1993. Occurrence of arctic cod (Boreogadus saida) schools and their vulnerability to predation in the Canadian High Arctic. Arctic 46(4):331-339.

WILDLIFE COMPUTERS. 1994. Satellite-linked time depth recorder v. 3.11: Instruction manual. Redmond, Washington: Wildlife Computers. 80 p. 